J. Product. \& Dev., 16(3):459-481(2011)

بعض القيم السياسية لطلاب الجامعة الريفيين وعلاقتها

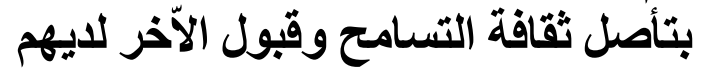

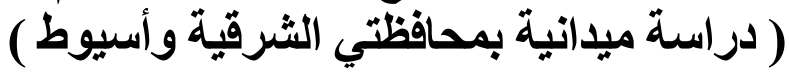

إبراهيم عبد الرحمن علي خليفة

قسم علم الاجتماع الريفي ـ كلية الزر اعة - جامعة الأزهر بأسيوط - مصر علئه

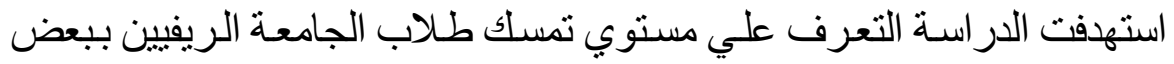

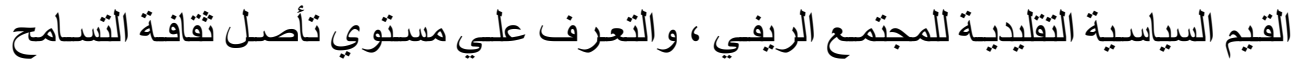

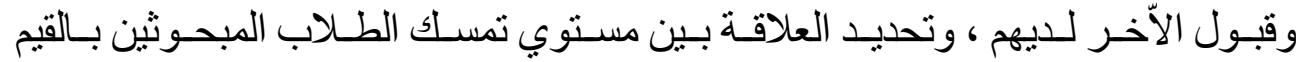

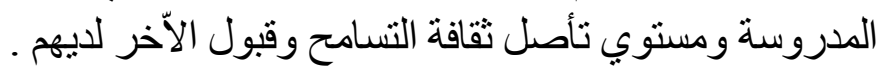

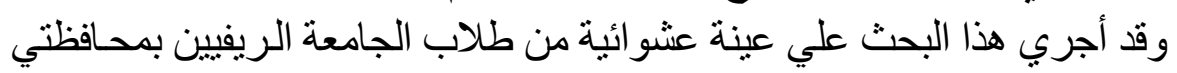

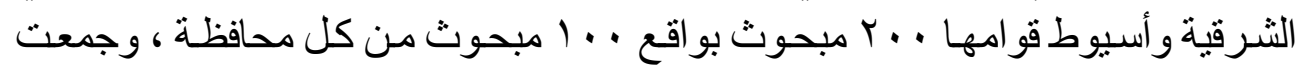

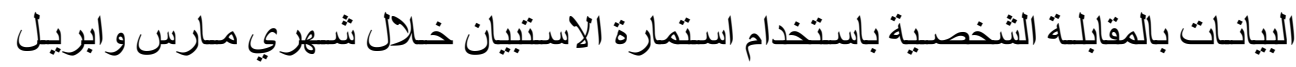

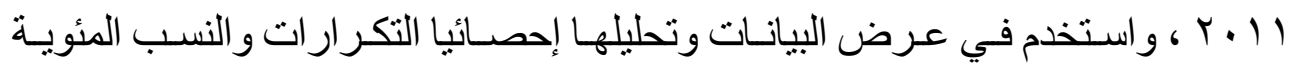

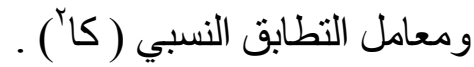

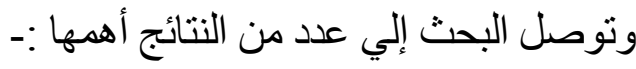

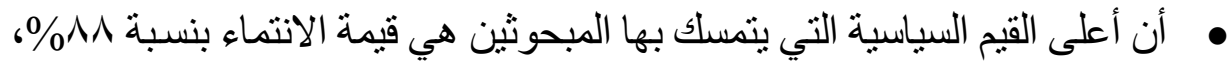

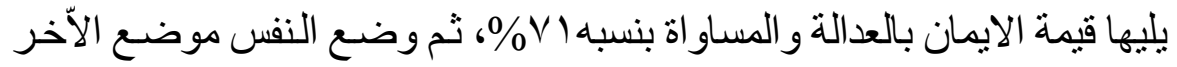

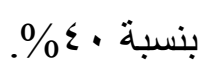

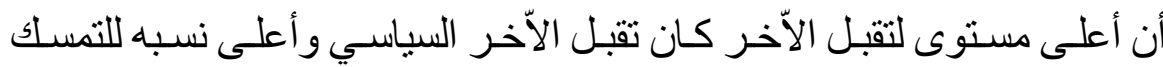

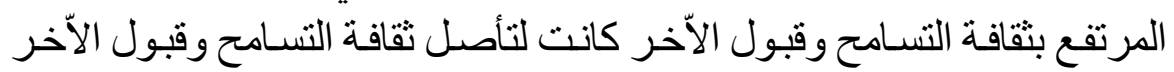

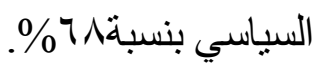

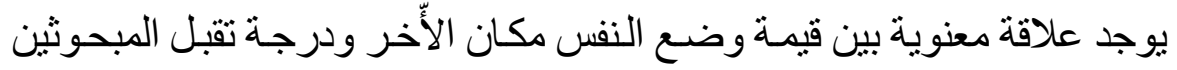

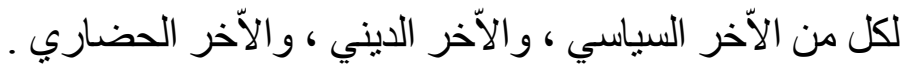




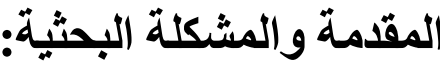

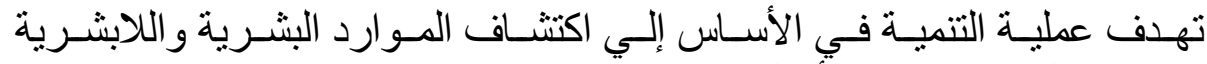

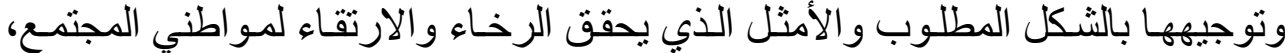

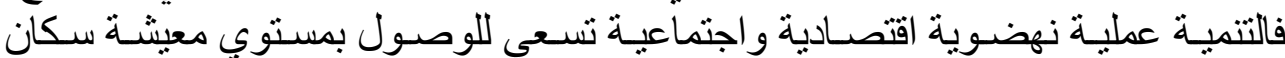

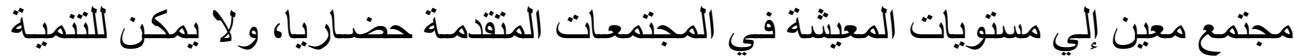

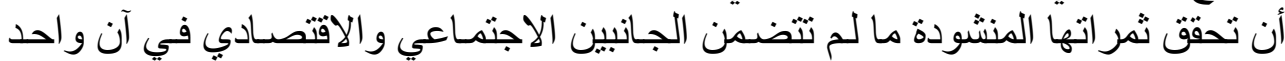

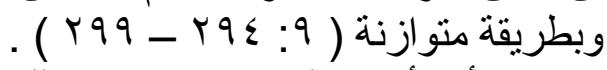

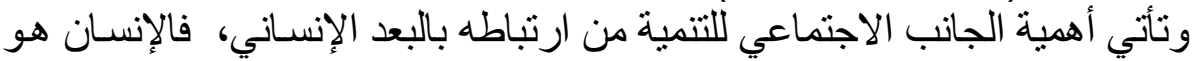

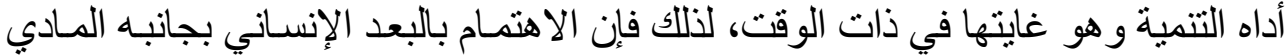

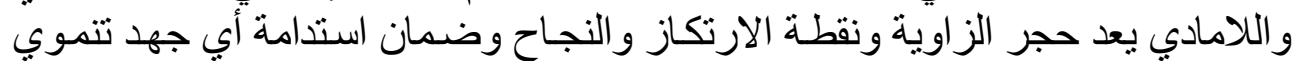
. $\left(r_{0}-r_{0} \cdot-i v\right)$

وتأتي القيم في مقدمة مكونـات الجانب اللامـادي للإنسـان؛ حيث أنها تعد بمثابـة الإنية

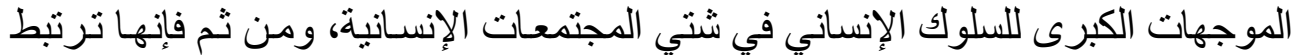

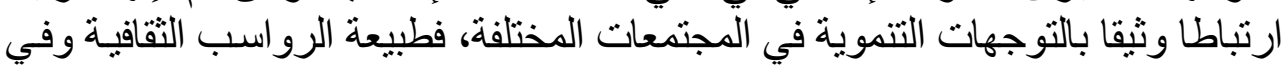

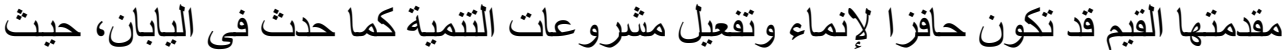

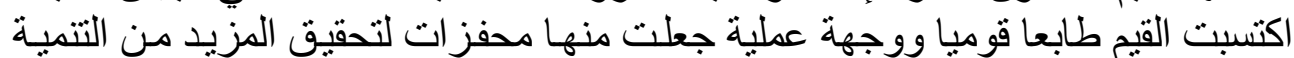

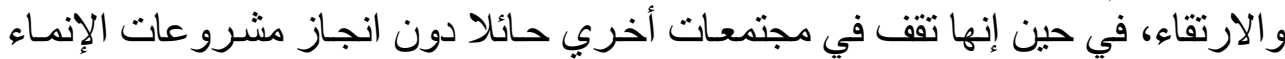

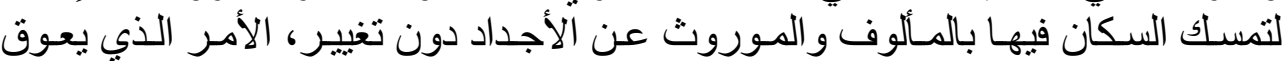

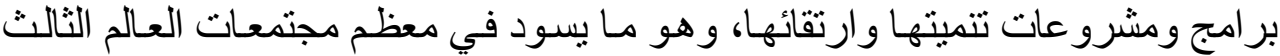
. ( (1)- Ir: $1 \varepsilon)$

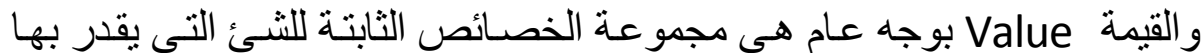

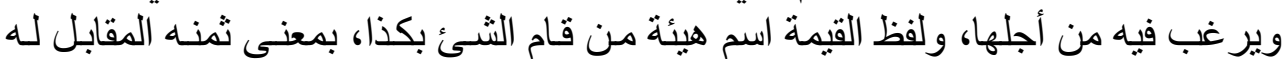

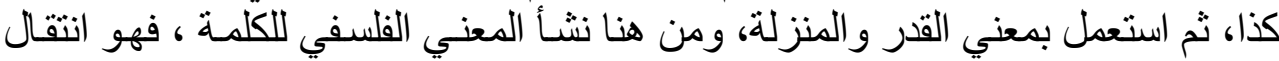

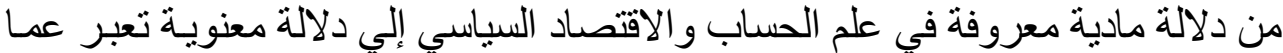

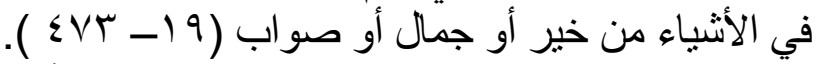

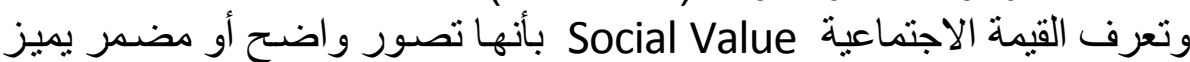

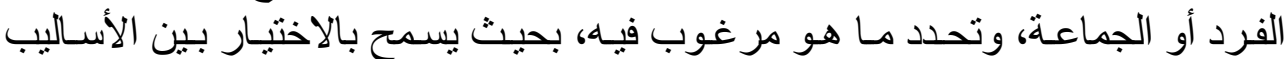

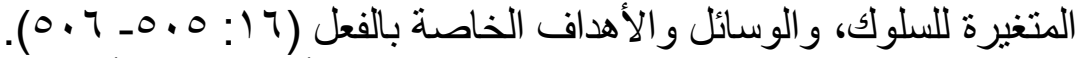

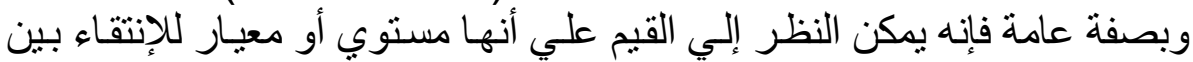

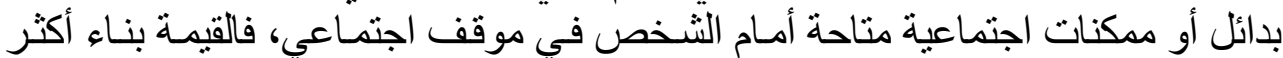

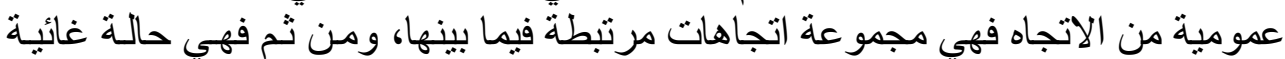

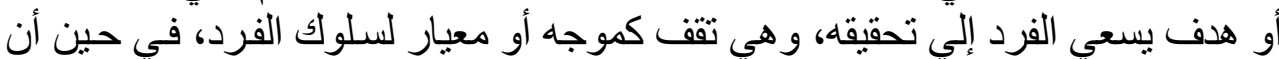

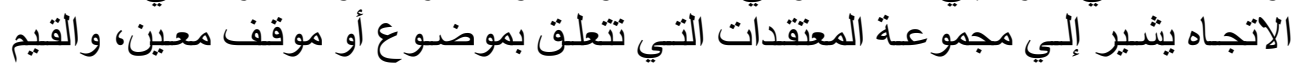


الإنسانية تعد جوهر الكيان الاجتمـاعي لأي مجتمع إنسـاني، فهي محور ارتكاز الثقافة

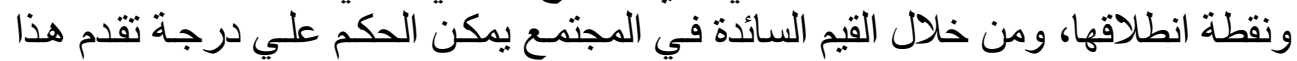

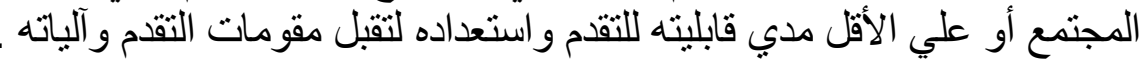

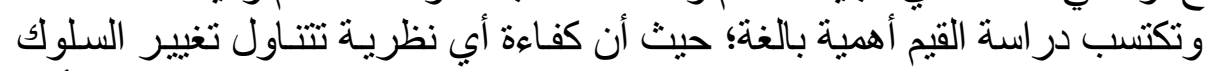
الإنساني و التنبؤ به يتوقف علي مدي اهتمامها بالجانب القيمي للسلوك أك الإنساني، كمـا أنها

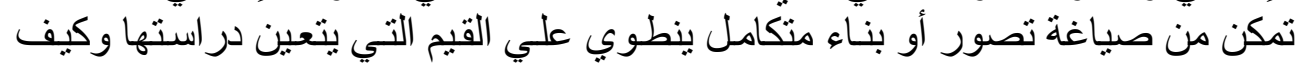

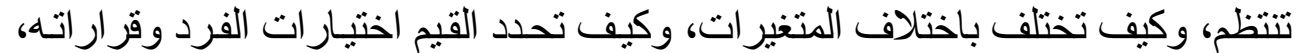

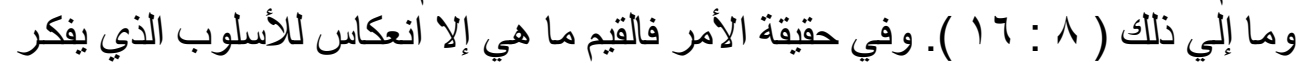

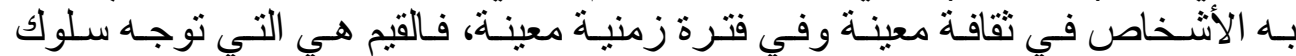

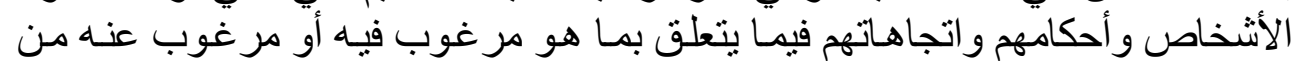

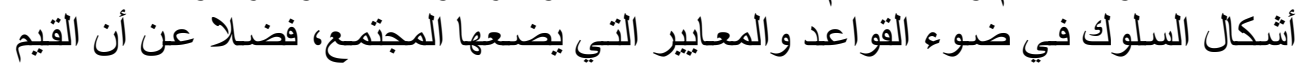

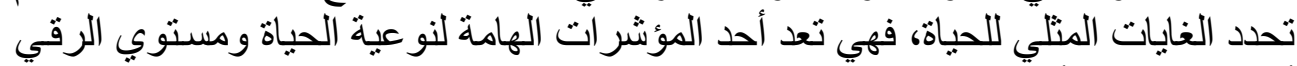

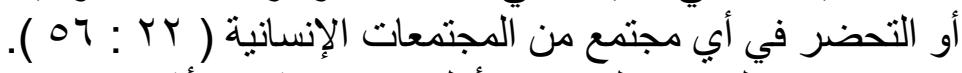

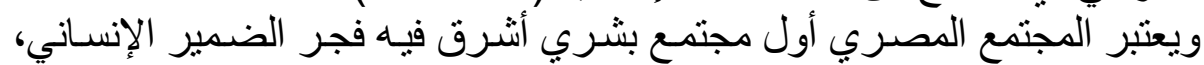

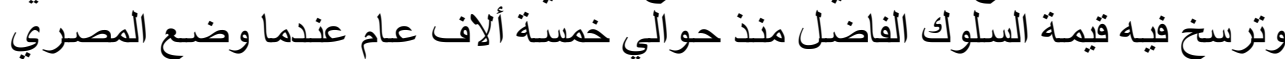

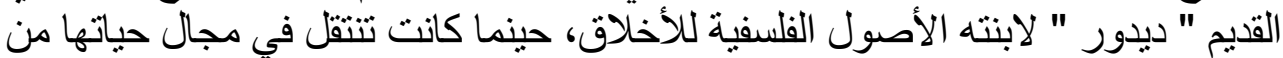

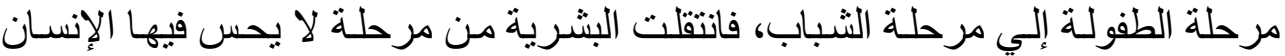

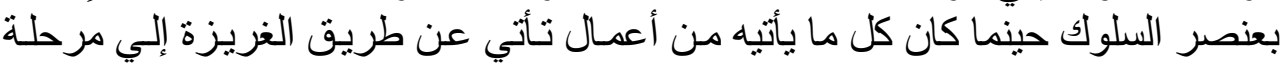

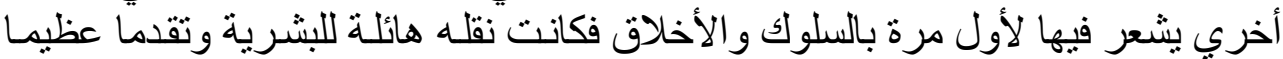

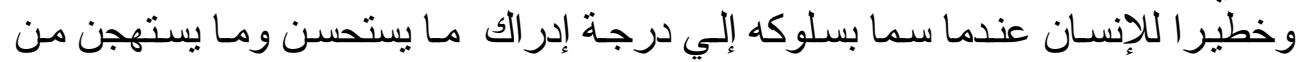

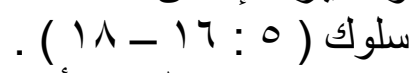

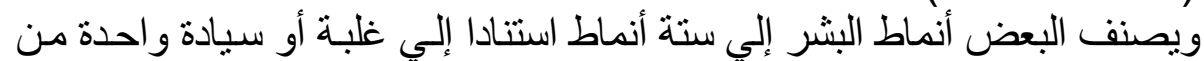

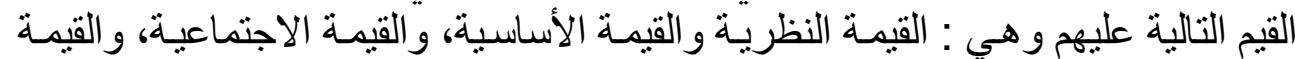

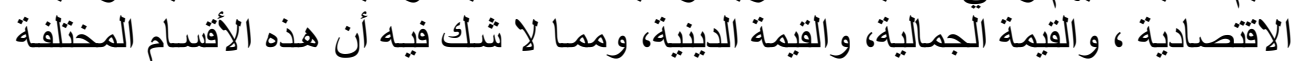

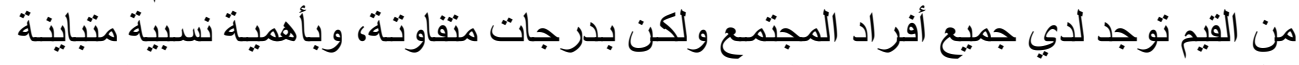
لكل منها وفقا لطبيعة الثخصية و الظروف الطية الاجتماعيـة و الاقتصـادية و الثقافية و السياسية

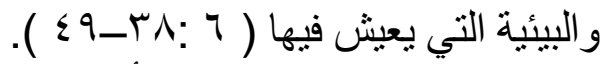
وتعتبر القيم السياسية من أهم القيم التي تؤثر علي مخي مختلف أنماط الحيـاة الإنسانية،

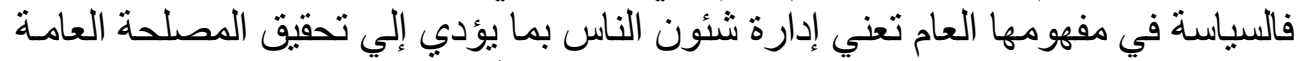

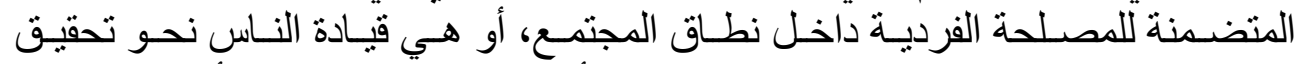

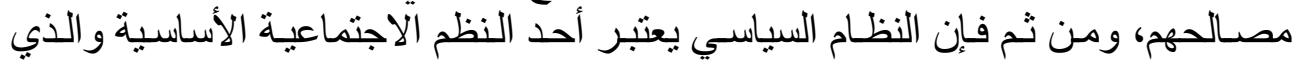
تحكمه مجموعـة القو اعد و المعـايير والقيم التي تنظم السلوك الإنسـاني في هذا المجـال . (s-r: 11) 


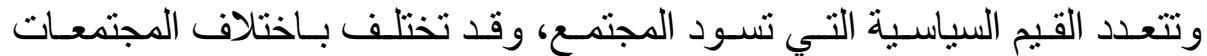

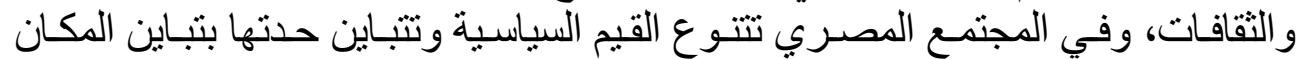
و الإنسـان، فـالريف يختلف عن الحضـر، الثباب يختلفون عن كبـار السـن، و المتعلمين يختلفون عن الأمبين، و هكذا . فيفي ويتسم الريف بكونه مستودع القيم و العادات و التقاليد وشتي أنماط السلوك التقليديـة،

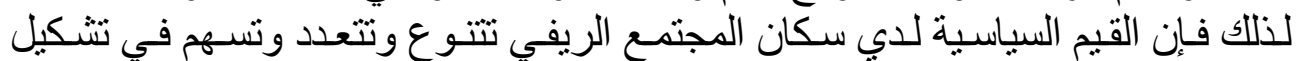

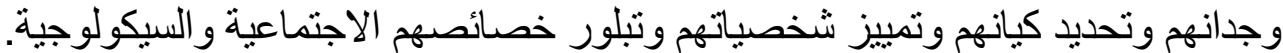

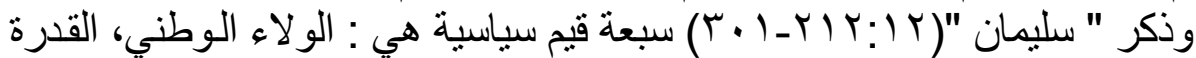

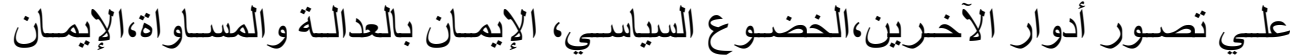

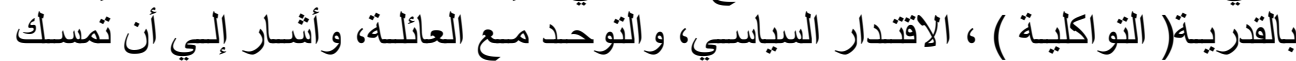

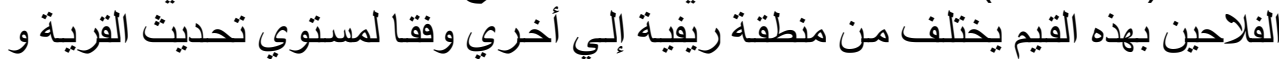

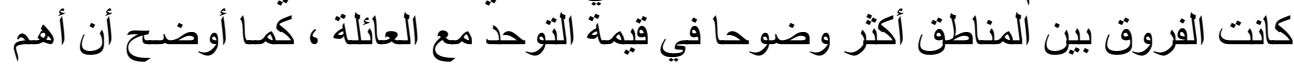

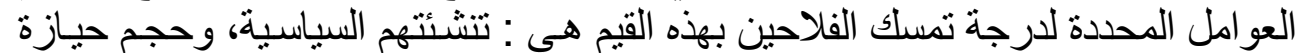

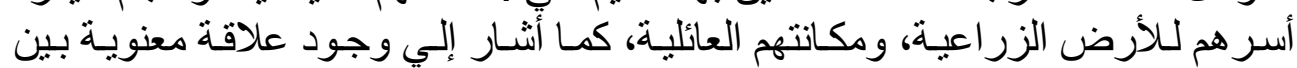

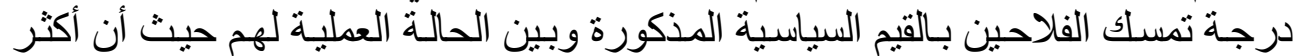

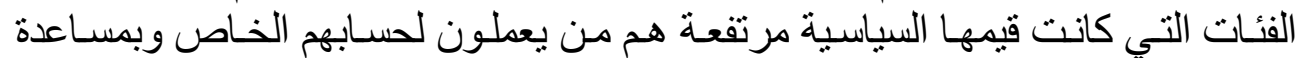

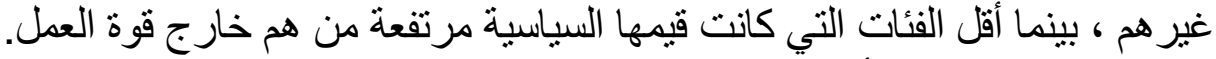

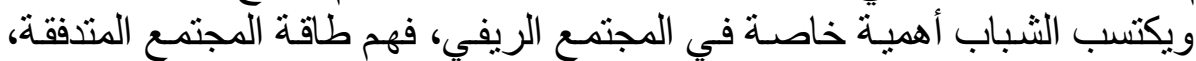

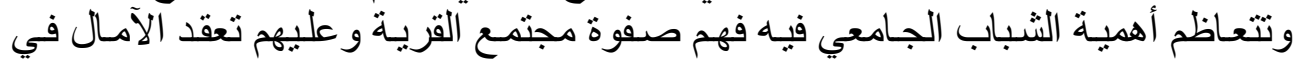

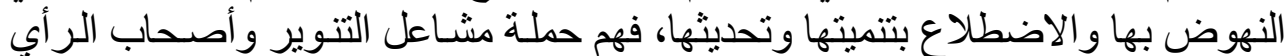

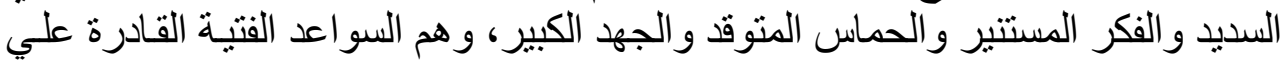

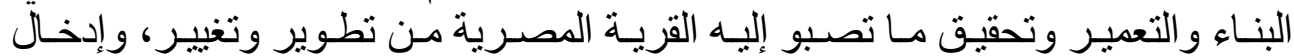

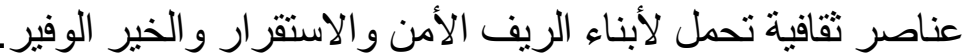

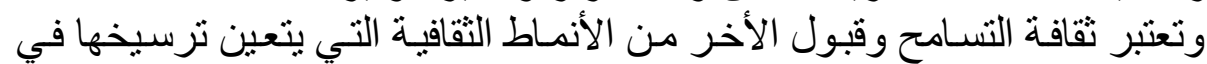

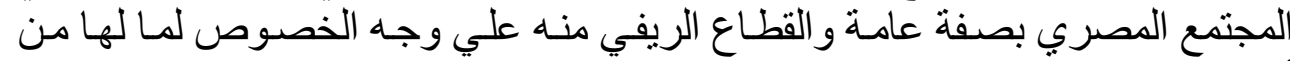

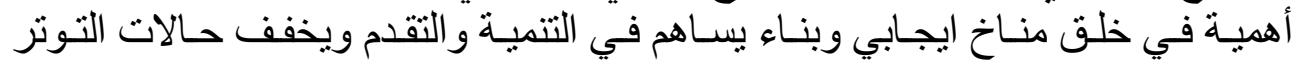

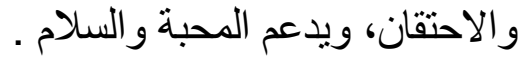

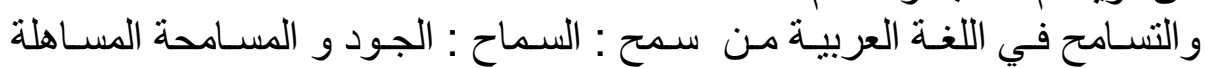

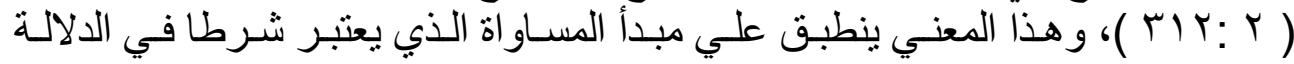

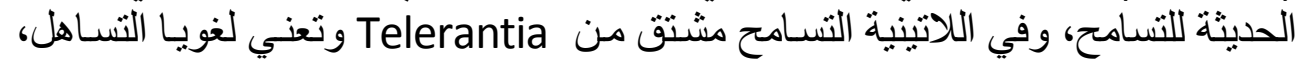

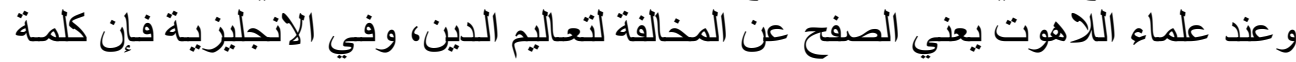

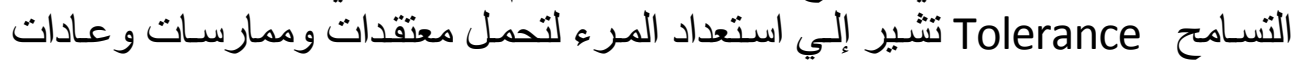
تختلف عمـا يعتقد، وهذا المصطلح يصف فعل التسـامح ذاته، أمـا اللفظ ومعلى 
فيشير إلى سياسة التسـامح في كل الآراء الدينية ، وأنشكال العادة المتناقضـة أو المختلفة

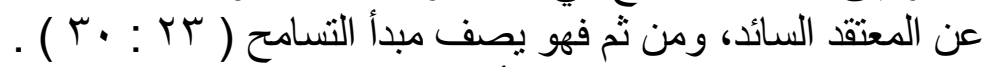

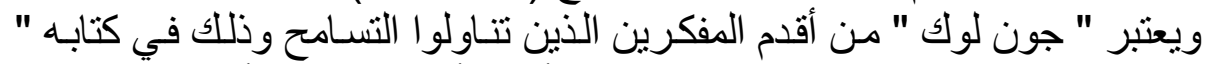

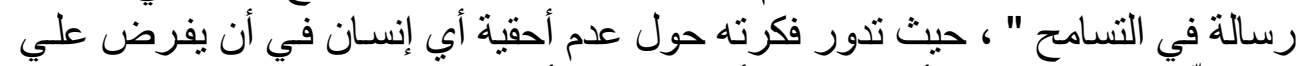

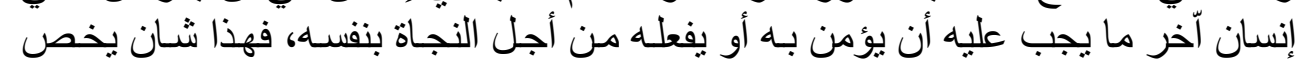

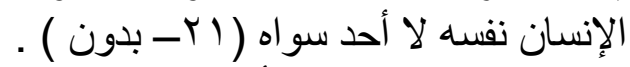

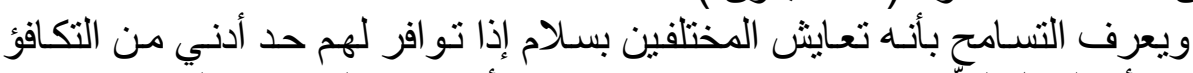

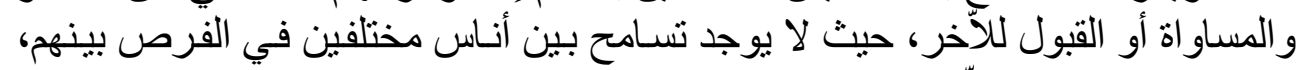

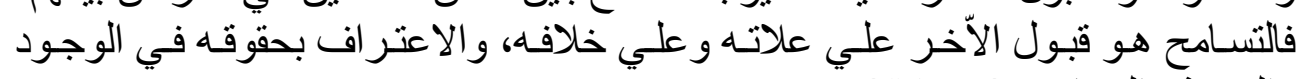

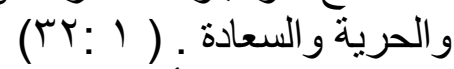

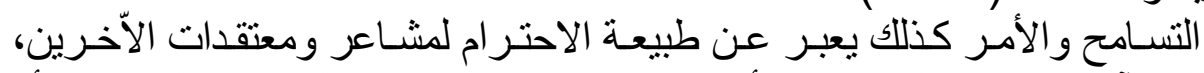

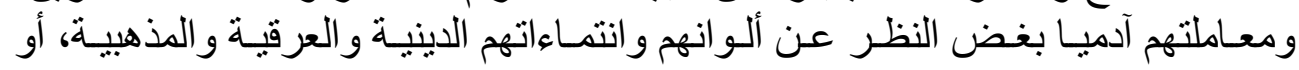

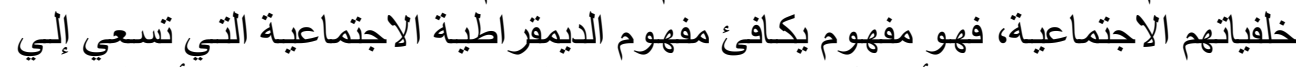

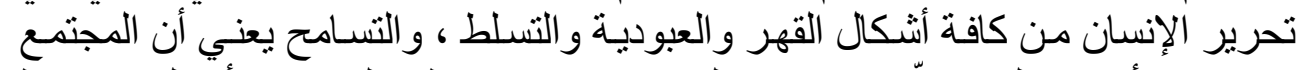

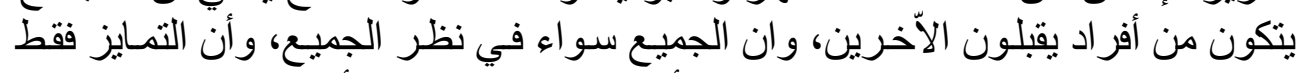

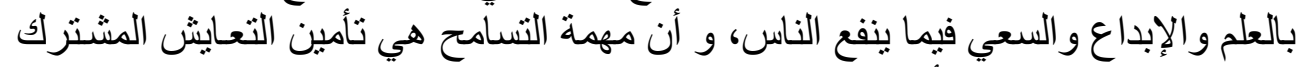

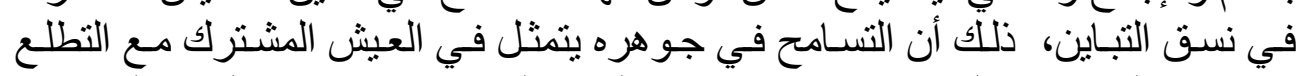

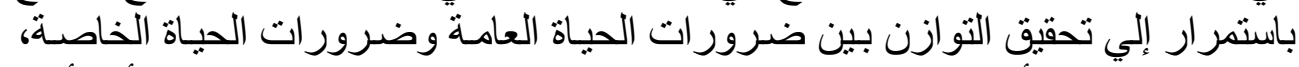

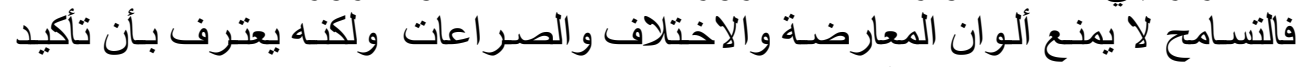

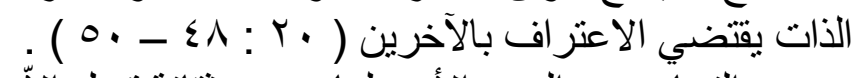

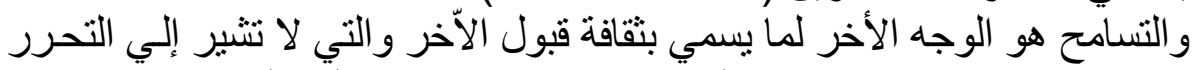

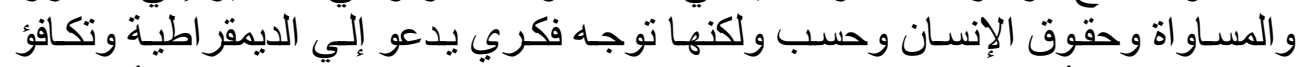

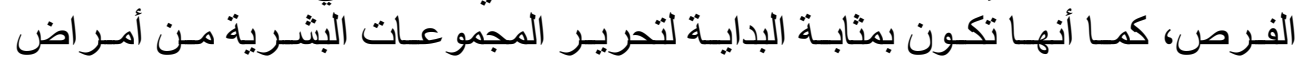

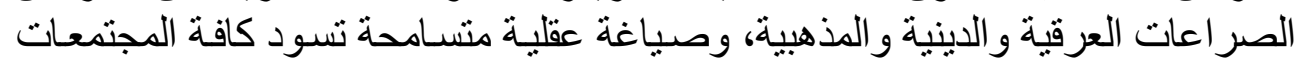

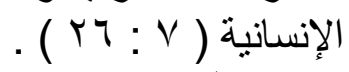

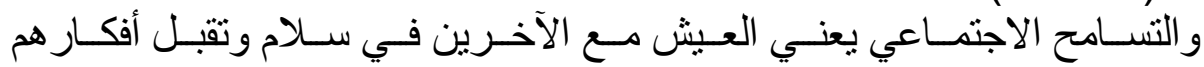

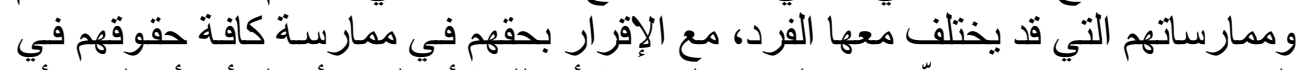

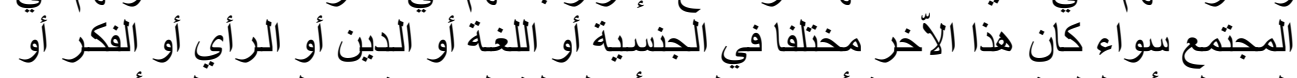

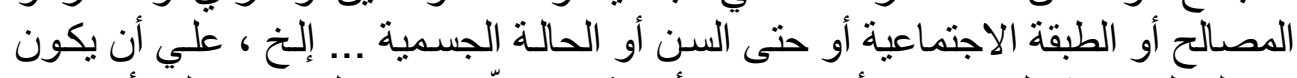

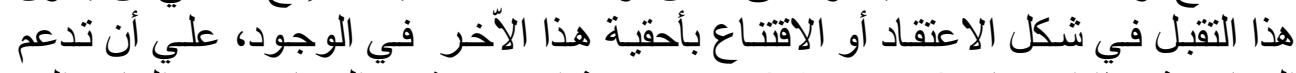

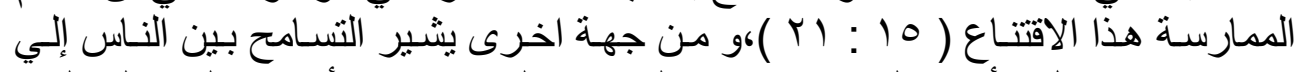

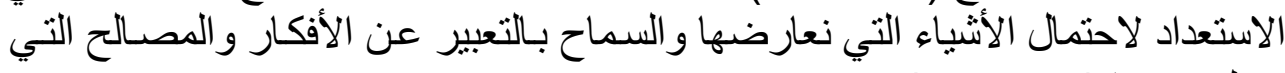

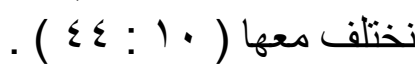


و إذا كانت الثقافة ليست ظاهرة مادية فحسب ولكنها طريقة حياة، فإن قيمة التسامح

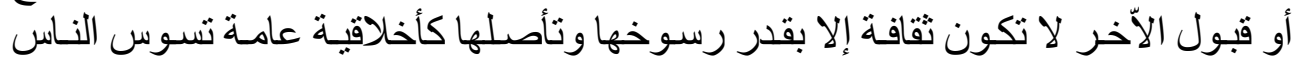
(1.: (1) (1)

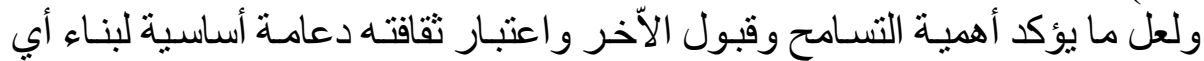

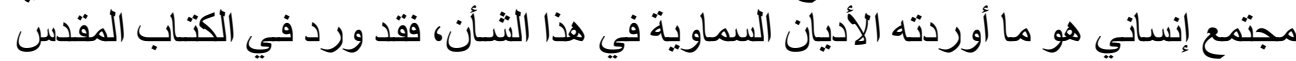

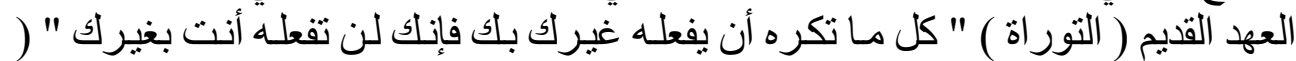

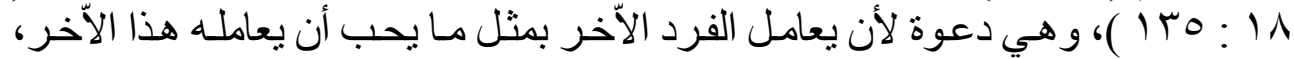

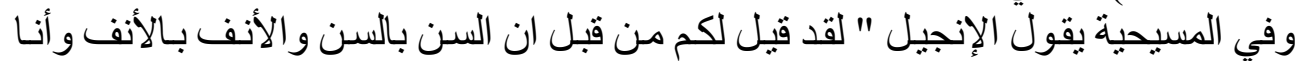

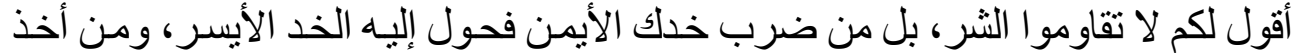

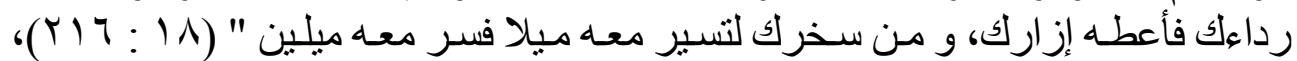

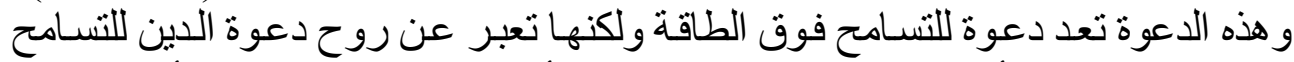

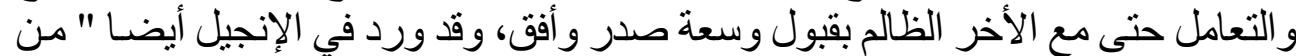

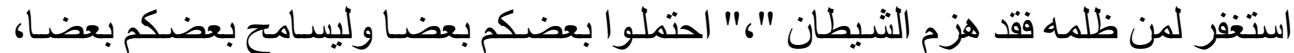
و إذا كانت لأحكم شكوى من الأخر فكما سامحكم الرب فسامحوا أنتم أيضا" (كرولوس :

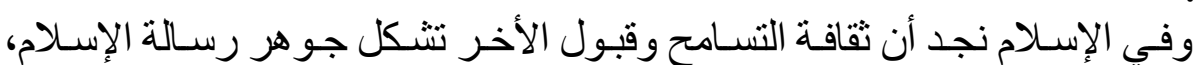

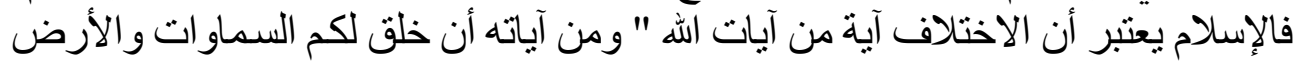

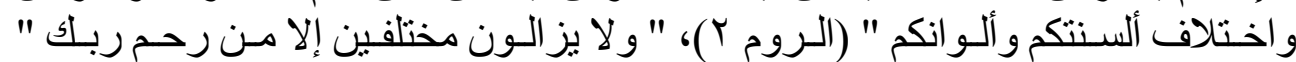

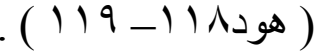

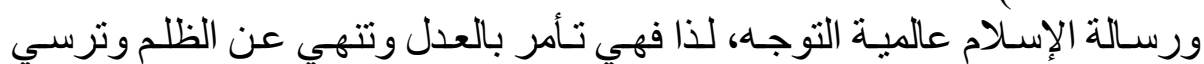

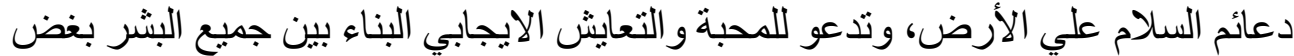

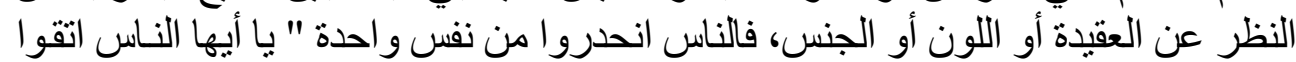

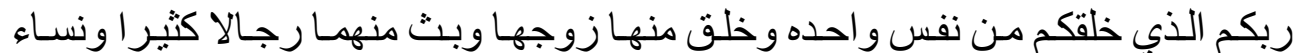

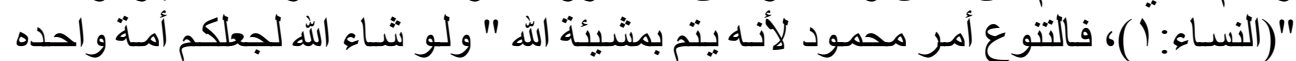

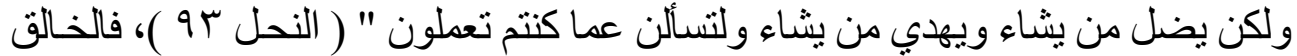

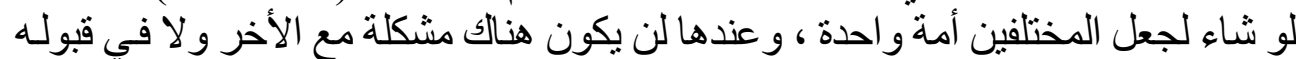

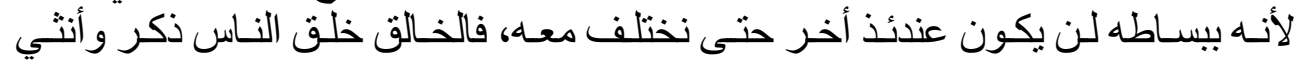

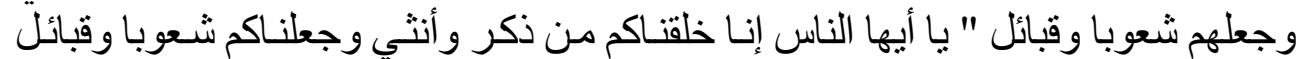

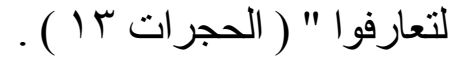

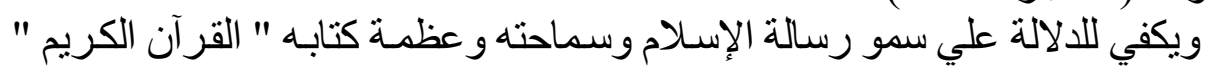

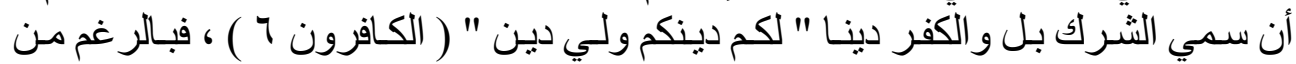

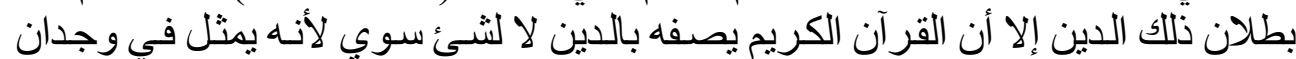
معتقيه دينا، فاله هو الذي خلق المؤمن و الكافر " هو الذي خلقكم فمنكم كافر ومنكم مؤمن لألئ 
" ( التغابن Y )، فالإسلام يحترم ما يعتقده الآخرون، ويوسع لهم في ذللك ولم يضيق عليهم

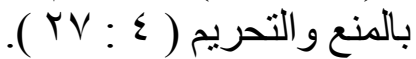

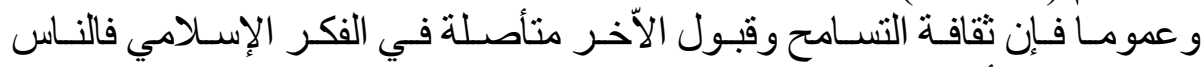

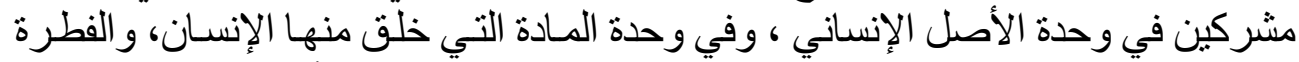

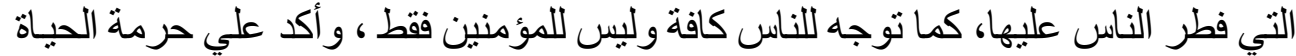

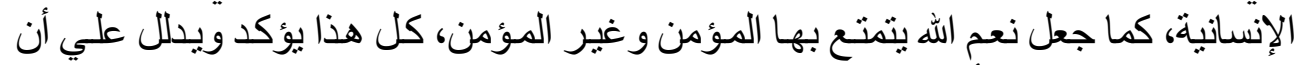

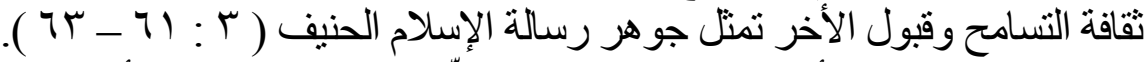

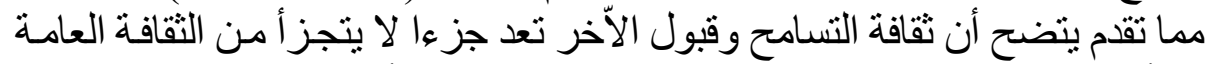

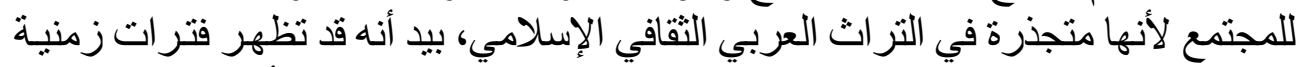

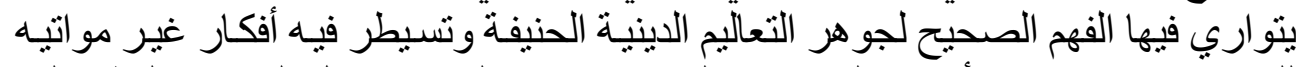

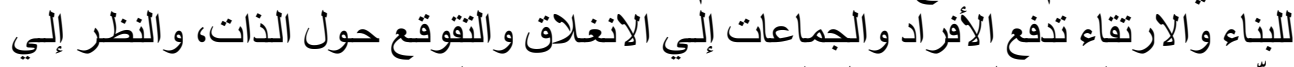

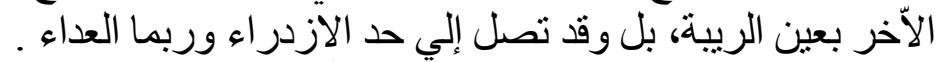

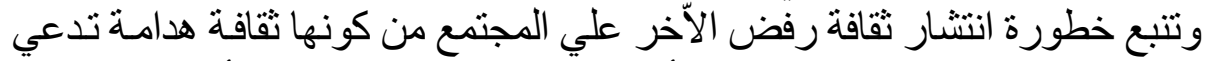

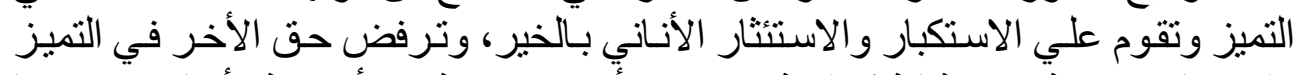

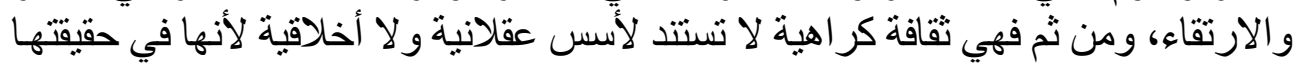

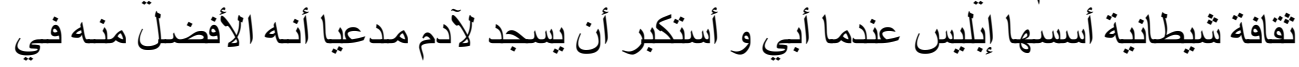

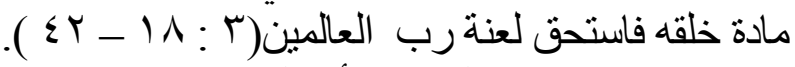

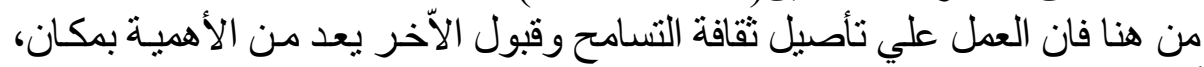

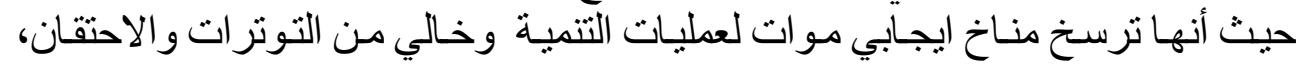

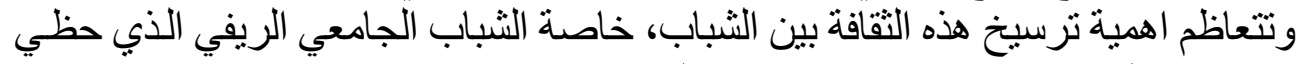

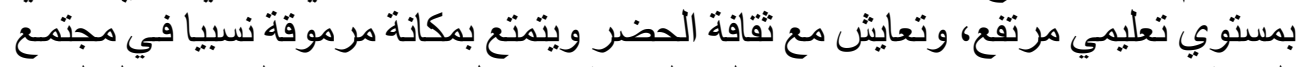

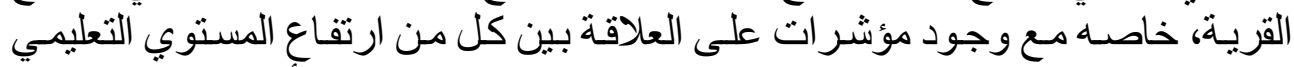

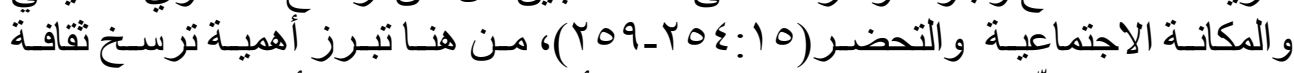
التسامح وقبول الآخر في المجتمع الريفي حيث أنه يعتبر القطاع الأكثر احتباجـا للتنمية

ونظر الأهمية الدور الذي يمكن أن يضطلع بـه الثباب الجامعي الريفي في تهيئة

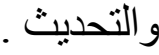

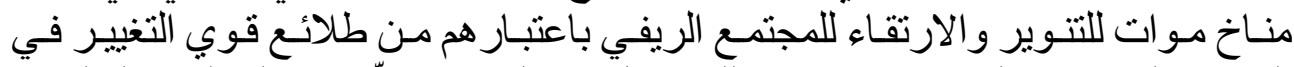

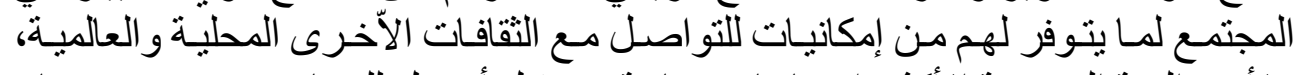

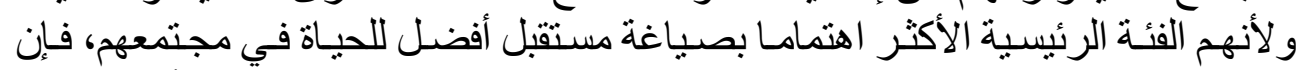

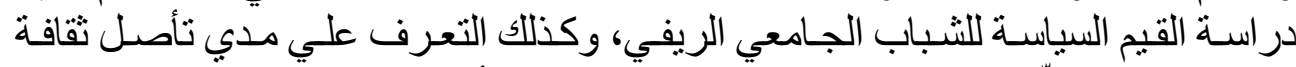

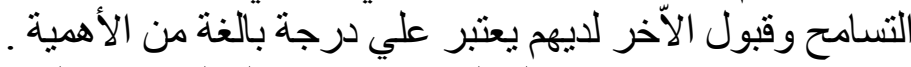

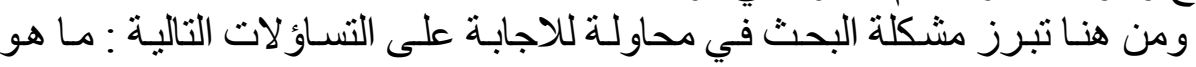

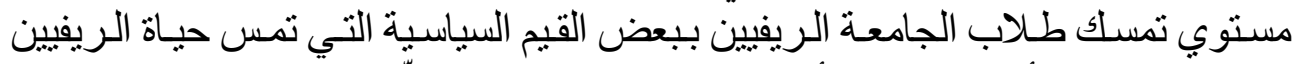

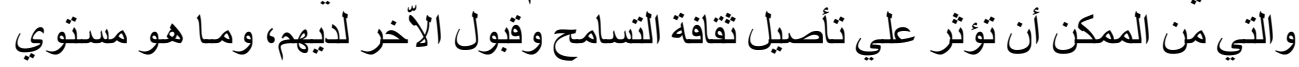


تأصل ثقافة التسـامح وقبول الآّخر السياسي و الديني والحضـاري لديهم، ومـا هي طبيعـة

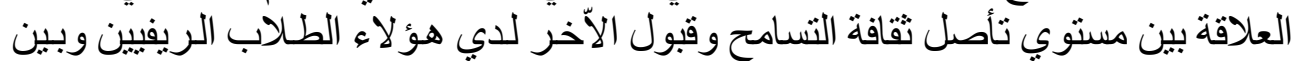

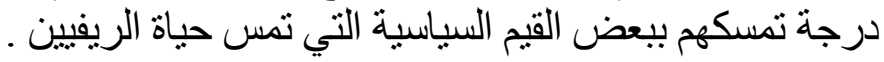

مما سبق وفي ضوع المشكلة البحثية استهرف هذا البحث ما يلي :-

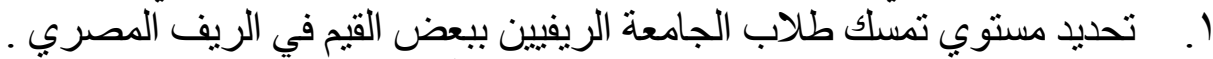

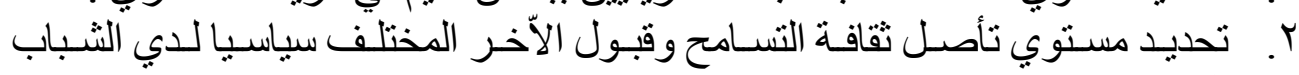

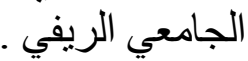

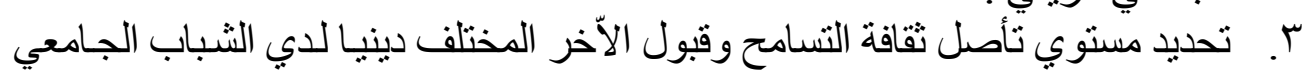

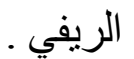

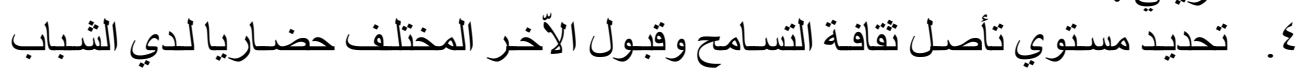

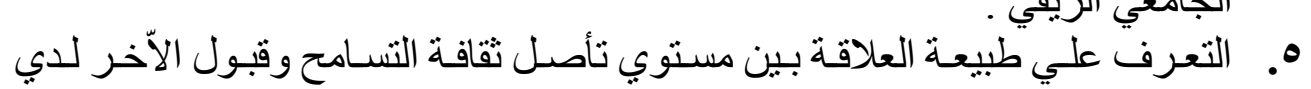

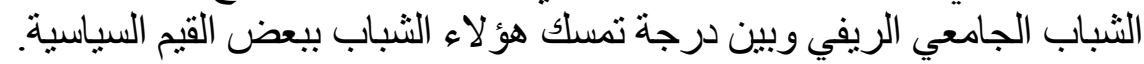

\section{الأهمية النظرية والتطبيقية للبحث :-}

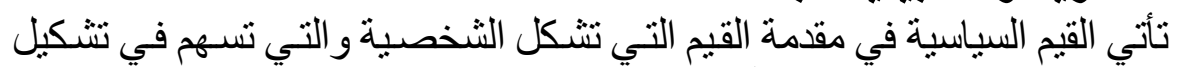

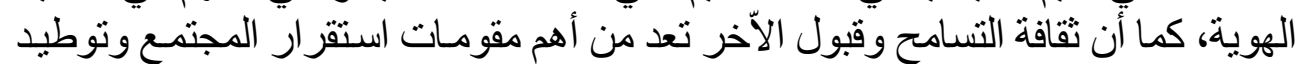

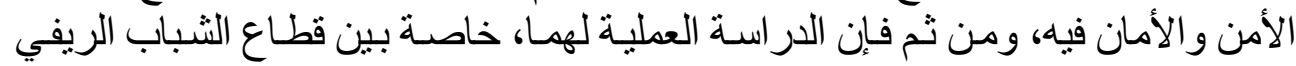

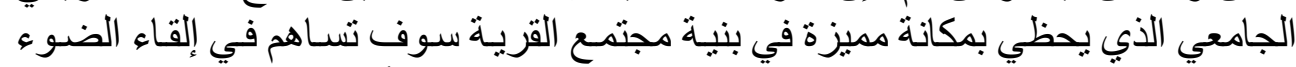

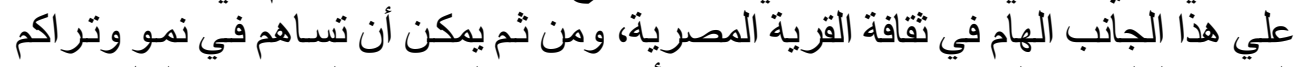

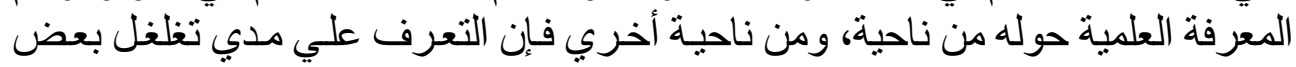

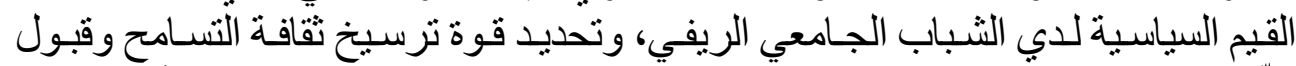

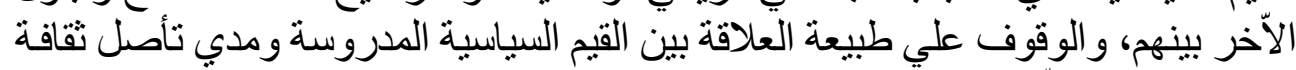

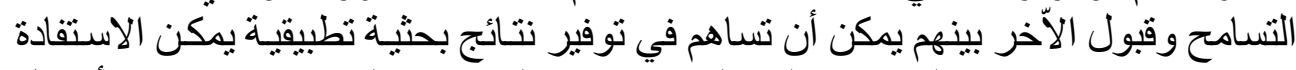

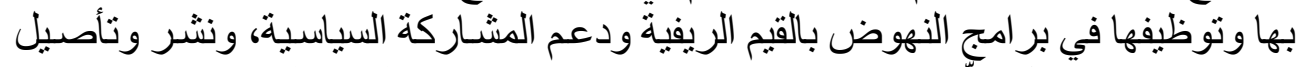

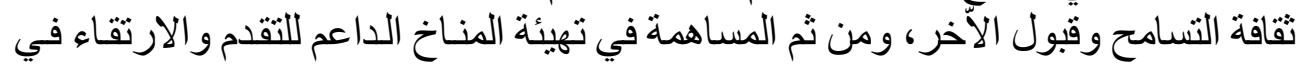
المجتمع الريفي.

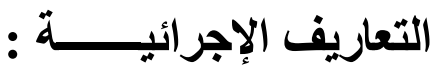

1. الاقتدار السياسـي : هو إحسـاس الفرد بمقدرتـه علـي التأثنير في مجريـات الأمـور

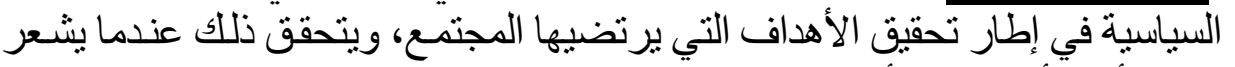

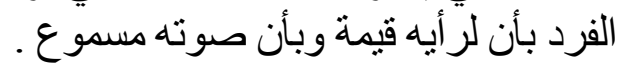




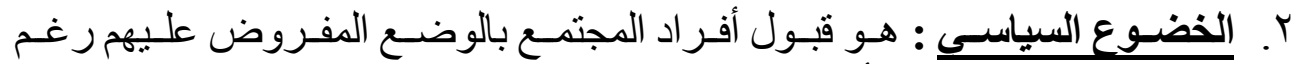

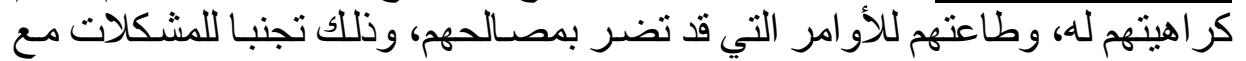

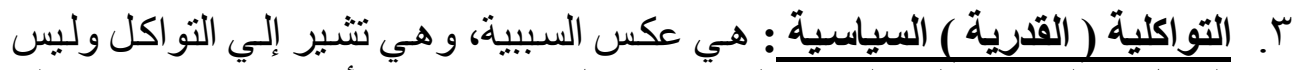

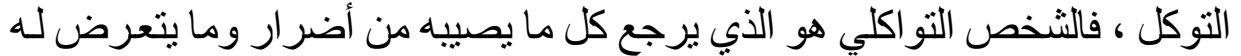

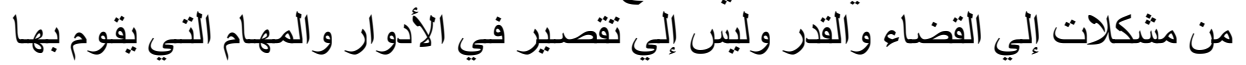

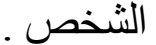

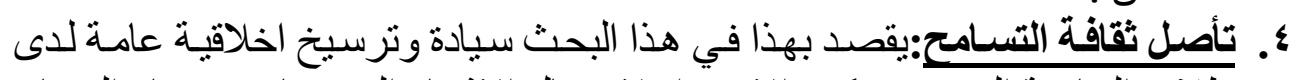

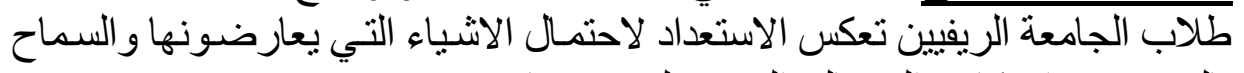
بالتعبير عن الافكار و المصالح التي يختلفون معها.

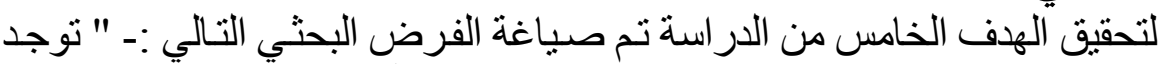

\section{القرض البحثي :}

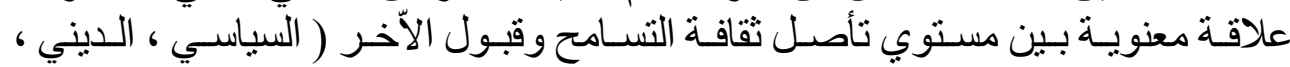

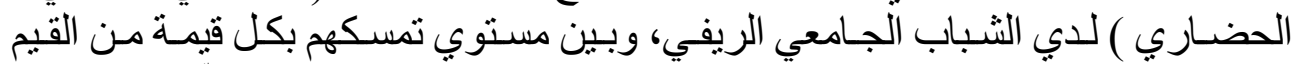

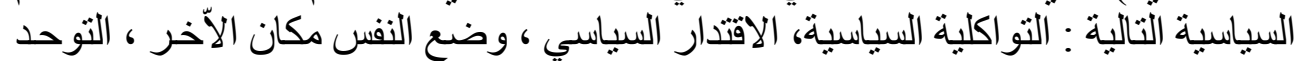

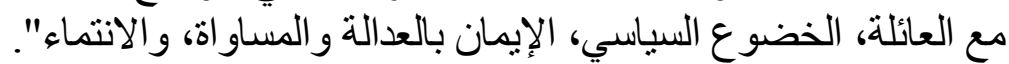

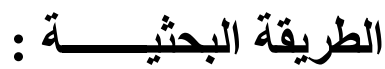

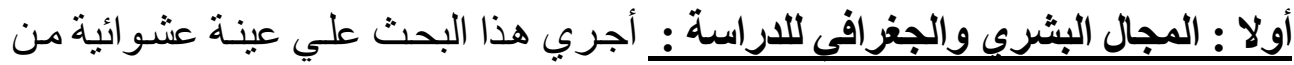

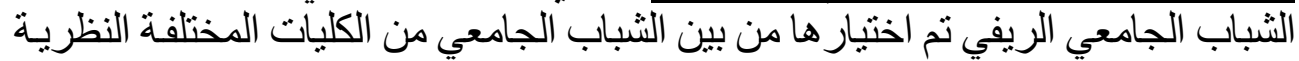

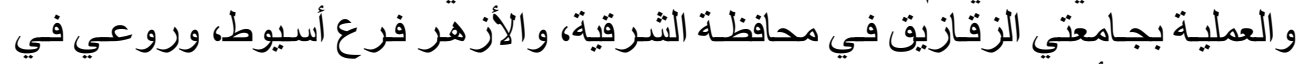

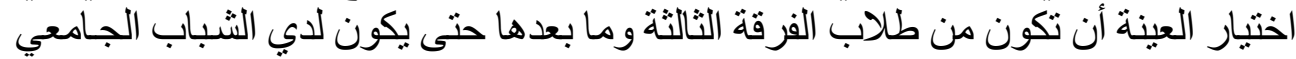

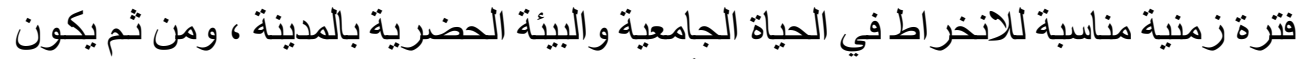

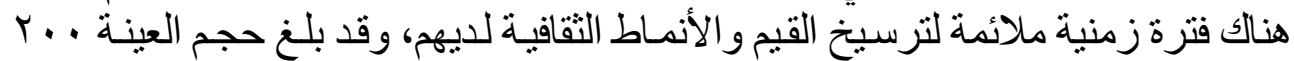

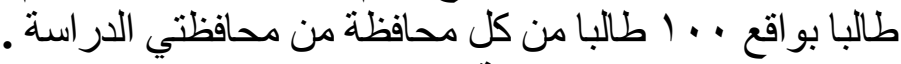

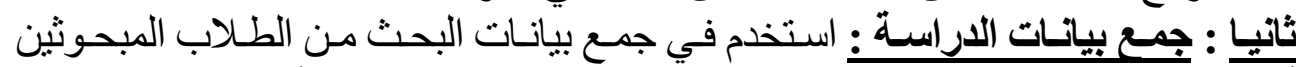

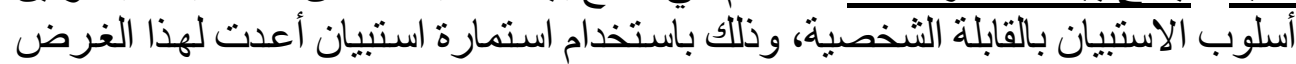

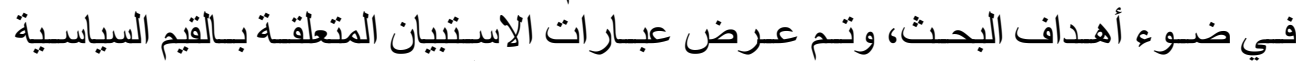

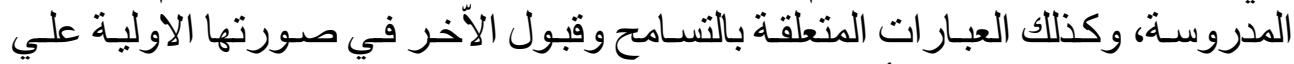

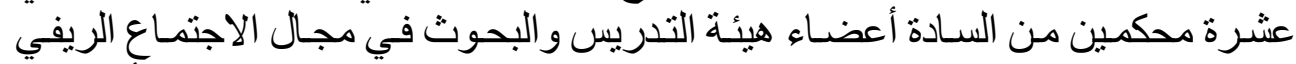

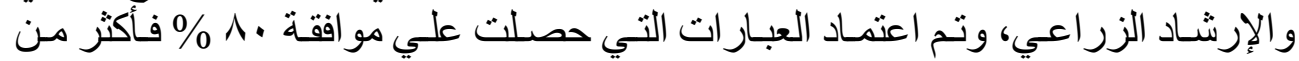

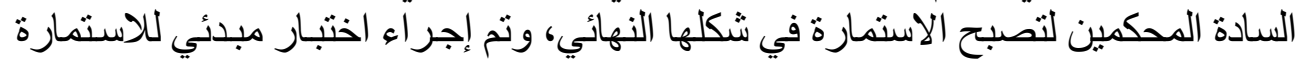

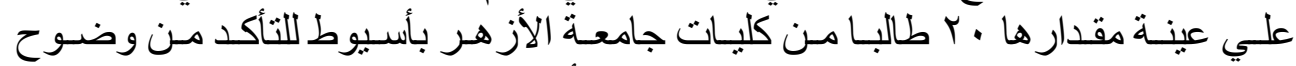

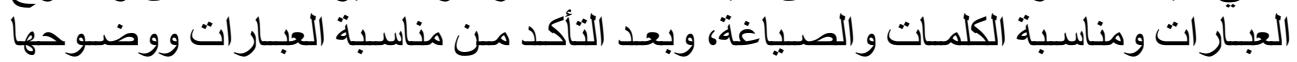


وصـلاحية الاسـتمارة، تـم جمـع البيانـات مـن المبحوثين خـلال شـهري مـارس، و ابريـل

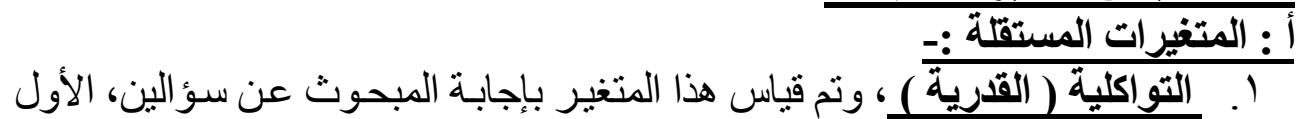

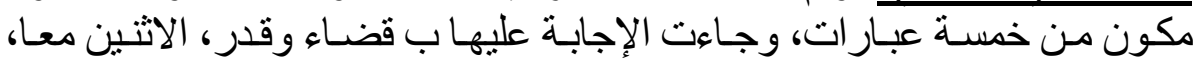

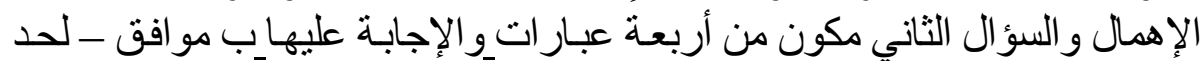

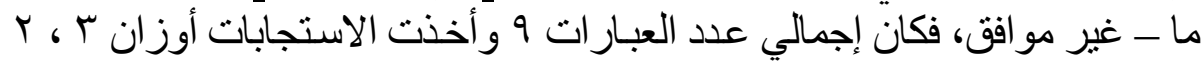

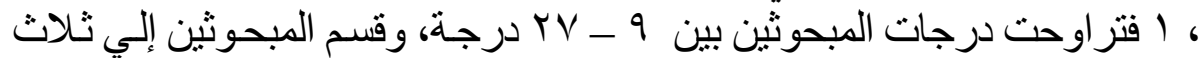

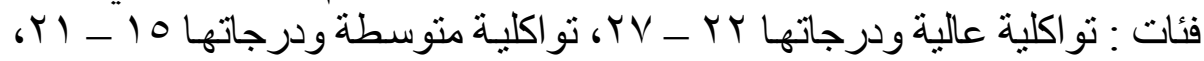

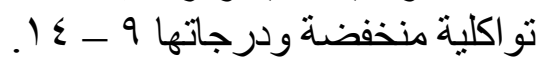

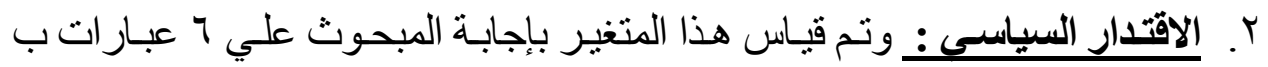

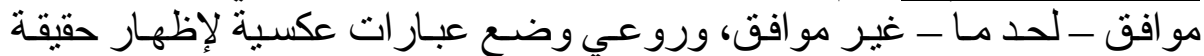

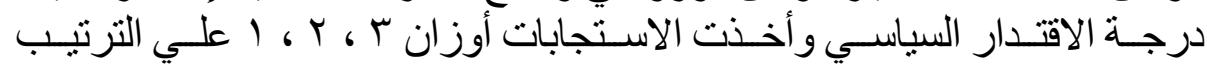

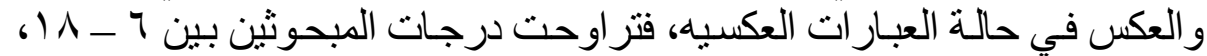

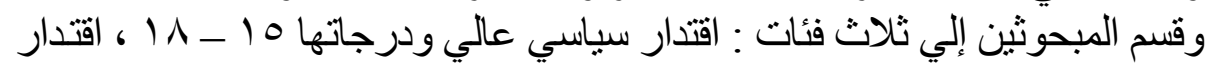

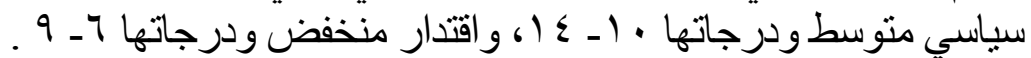

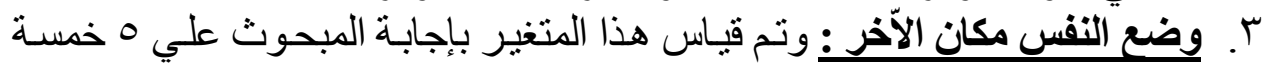

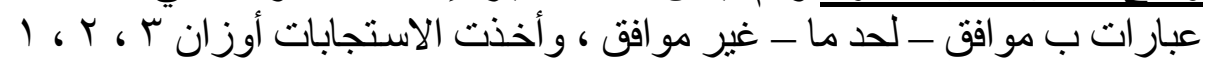

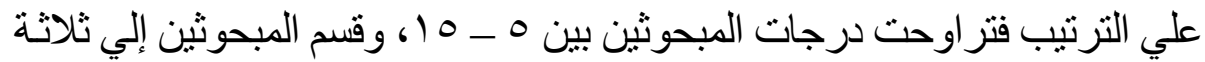

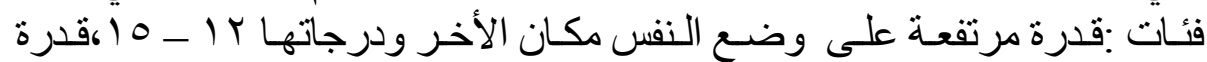

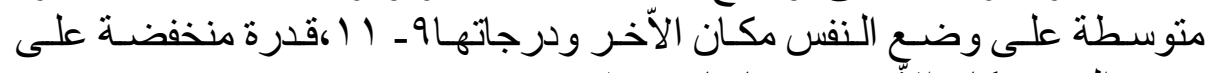

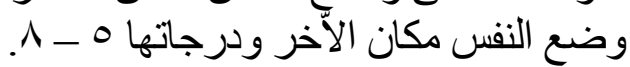

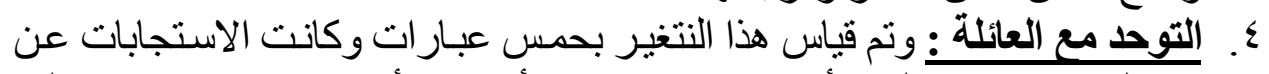

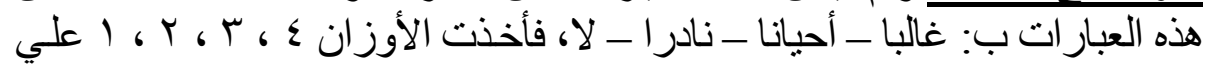

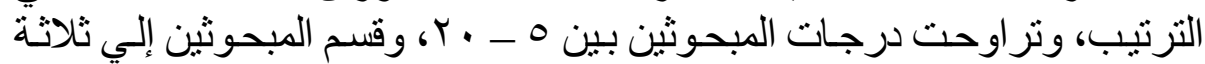

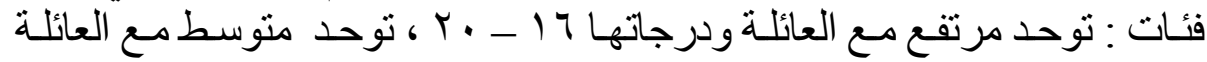

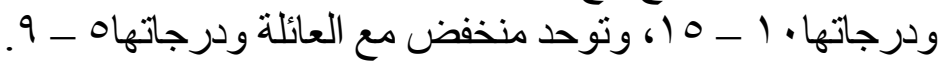

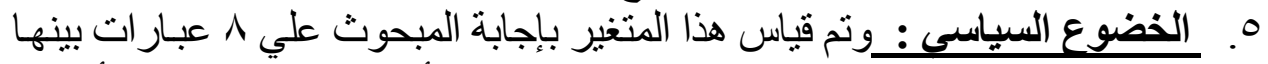

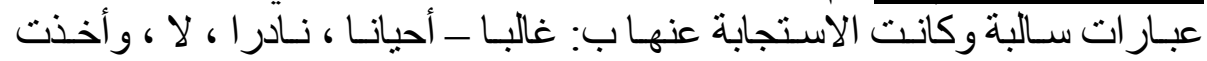

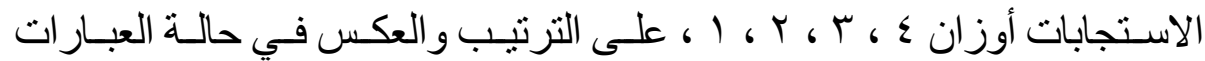

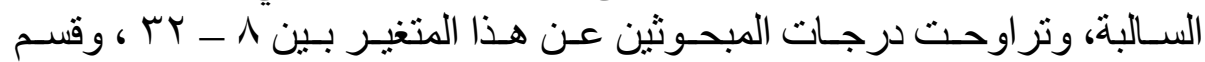

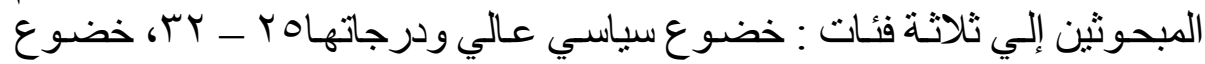

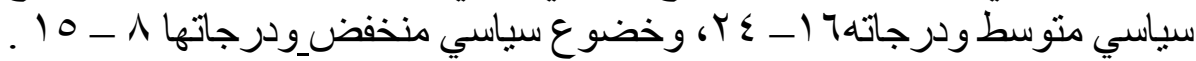




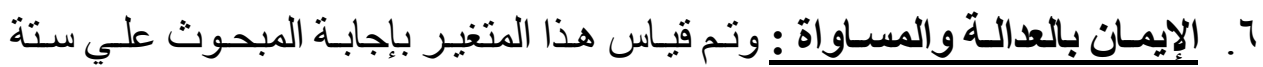

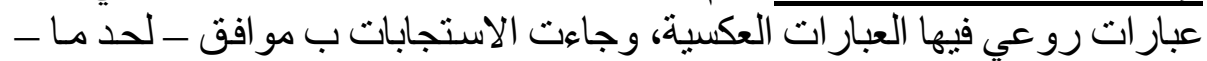

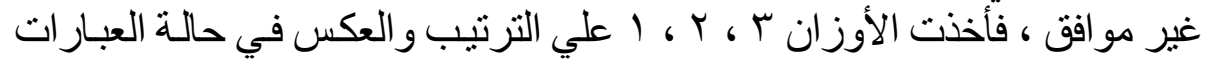

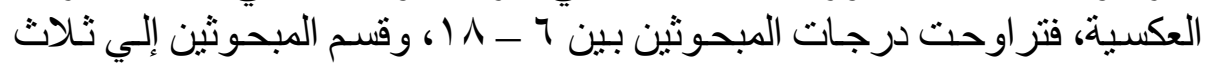

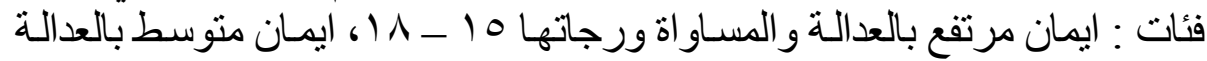

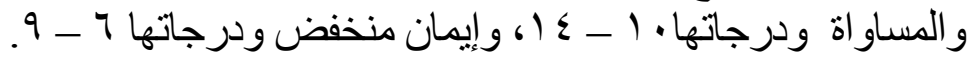

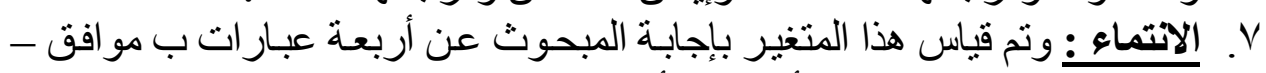

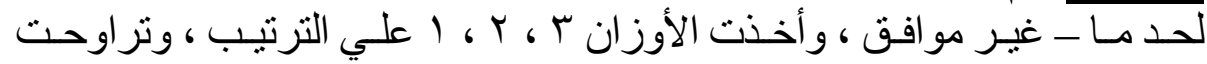

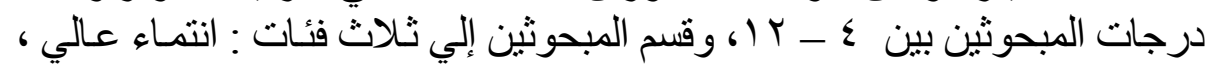

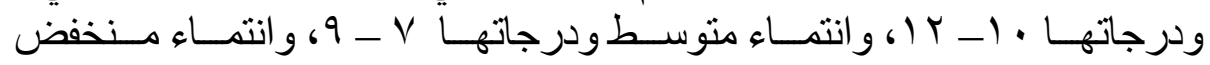

$$
\text { ودرجاتهاء - وردهاته . }
$$

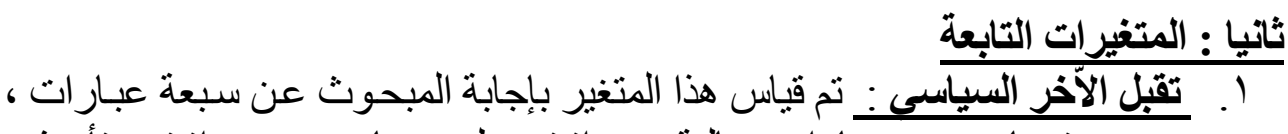

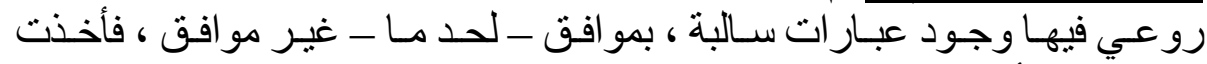

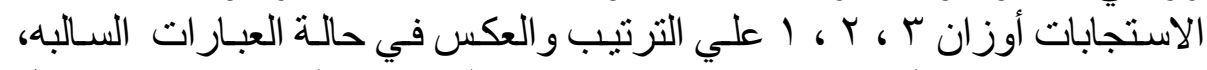

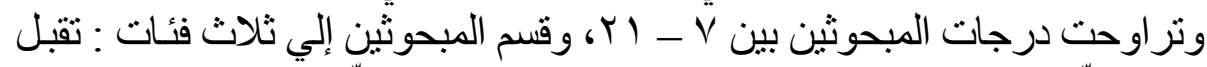

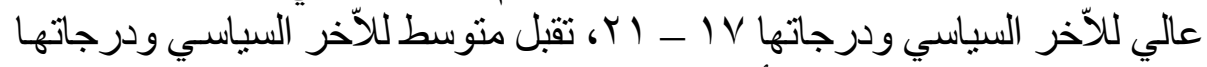

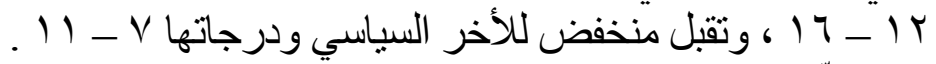

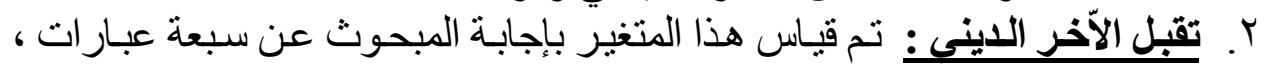

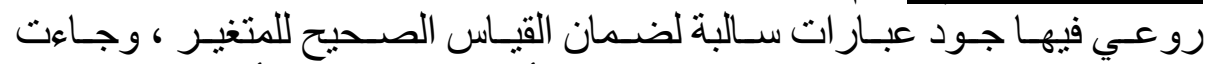

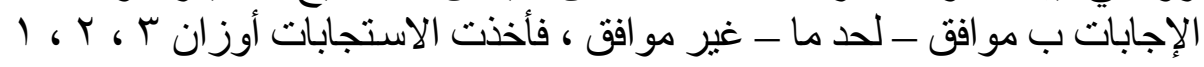

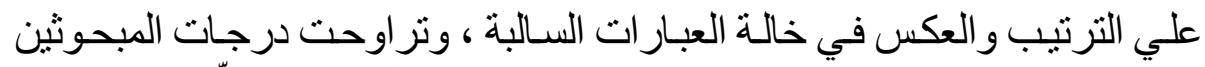

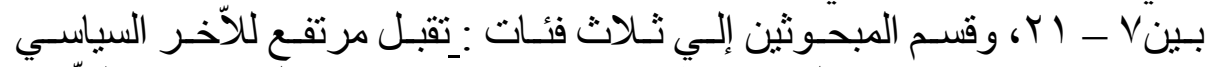

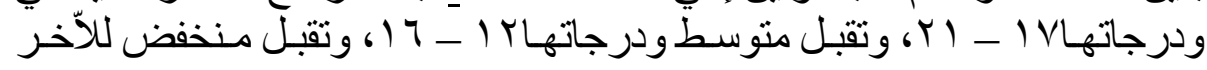

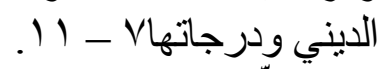

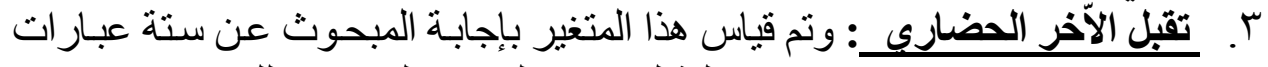

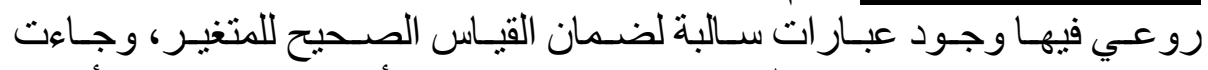

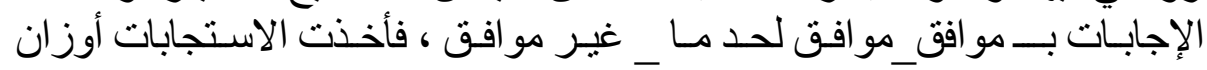

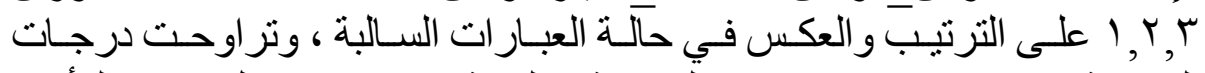

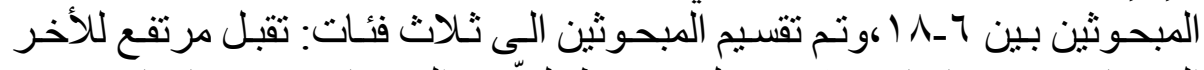

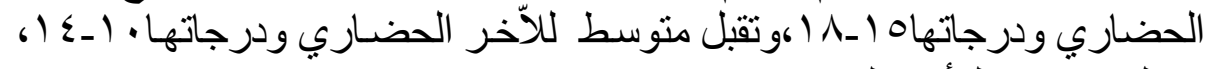
وتقبل منخفض للأخر الحضاري ودرجاتها 7 -9. 
رابعا : أدوات التحليل الإحصائى : تم تحليل البيانات باستخدام الأساليب الإحصائية التالية

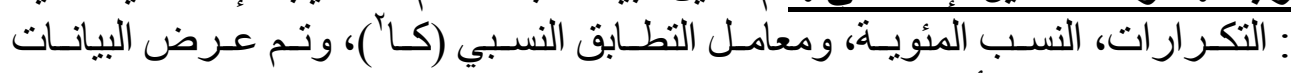
باستخدام الجداول والأعمدة البيانية .

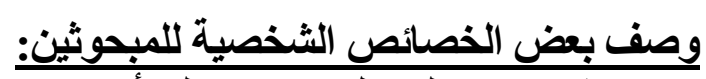

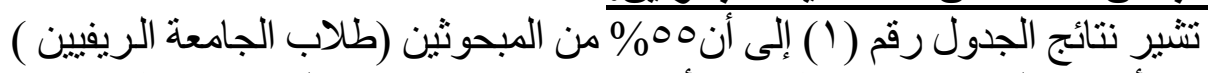

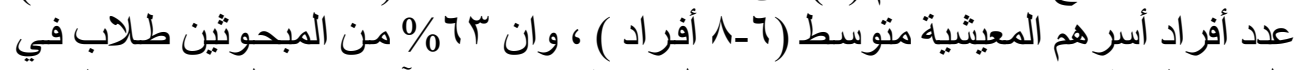

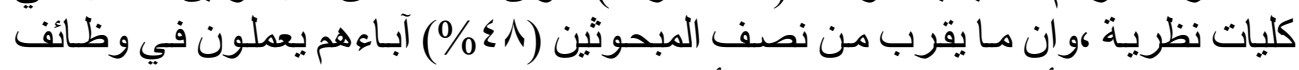

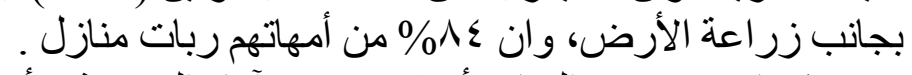

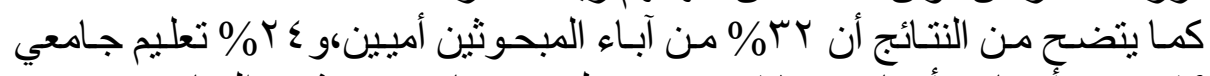

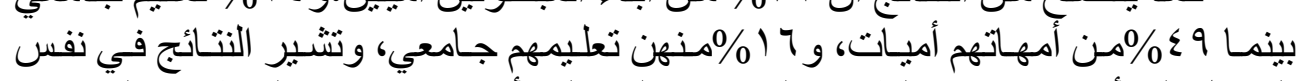

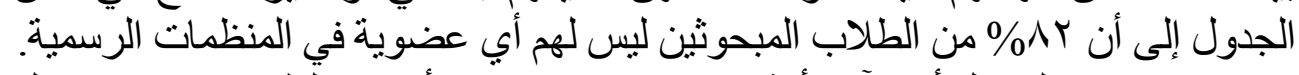

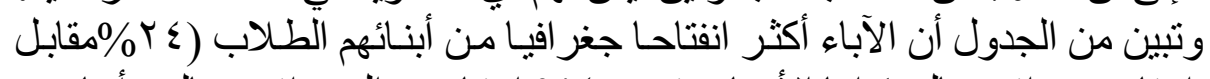

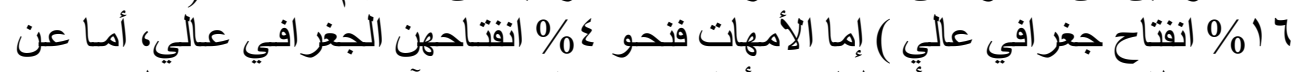

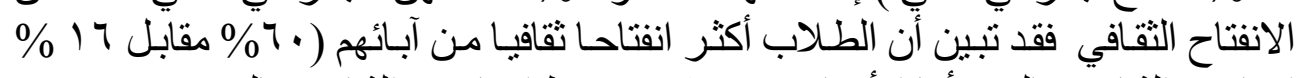

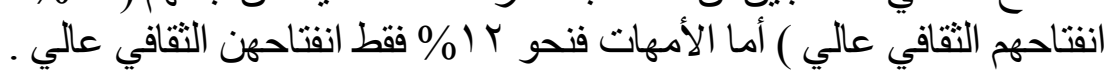

النتائج ومناقشتنها :

أولا:تحديد مستوى تمسك الثباب الجامعى الريفى بـالقيم السياسية التقليديـة

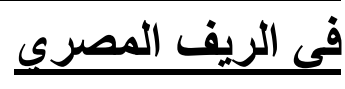

أوضحت النتائج (جدول رقم ץ) و الثكل البيانى (رقم / ) أن حو الي ثلاثة أخماس

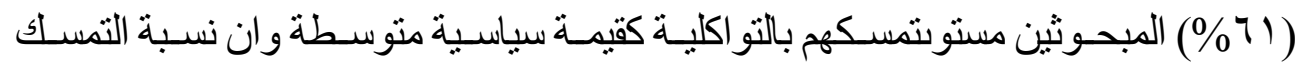

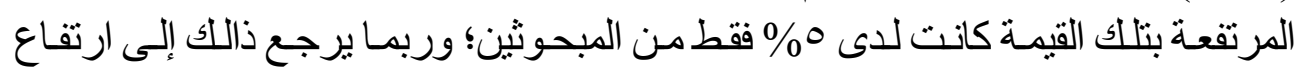

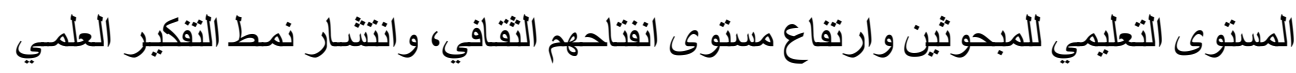

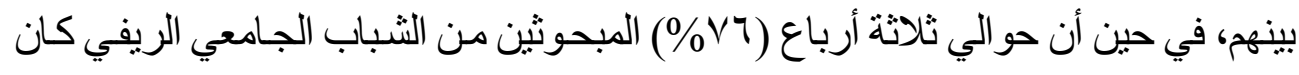

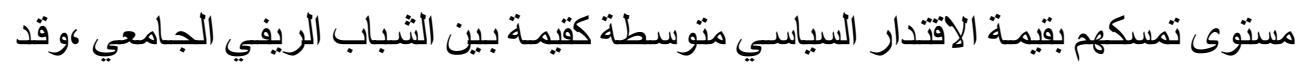

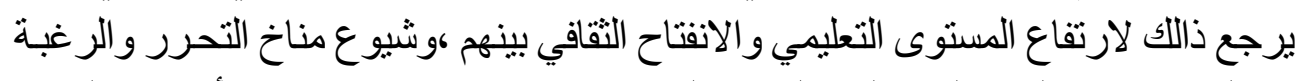

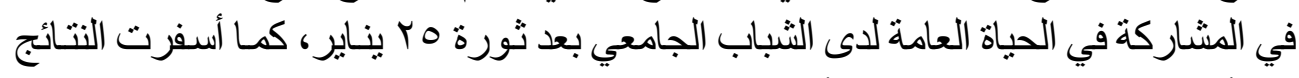

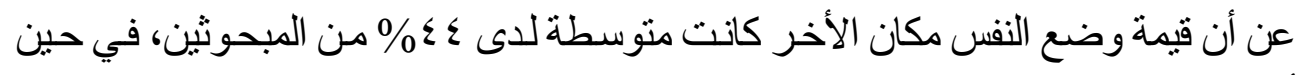

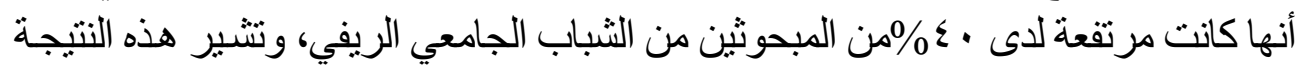

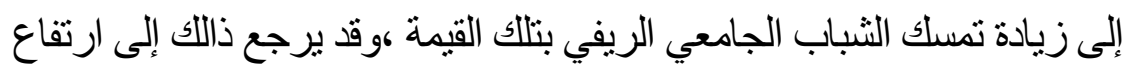


جلول رقم ( ) : وصف بعض الخصائص الثخصية للمبحوثين (عينة الاراسة )

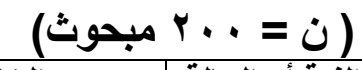

\begin{tabular}{|c|c|c|c|c|c|c|c|}
\hline الخاصية & الفئة أو الحالة & عدد & $\%$ & أخاصية & الفئة أو الحالة & عدد & $\%$ \\
\hline 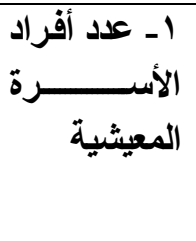 & 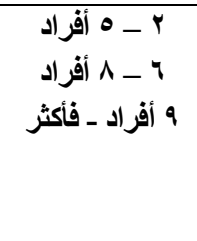 & $\begin{array}{l}\leqslant r \\
11 . \\
\leqslant 1\end{array}$ & $\begin{array}{l}r 1 \\
00 \\
r \varepsilon\end{array}$ & 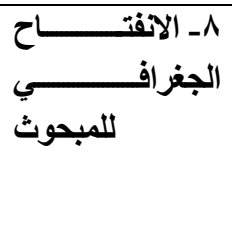 & 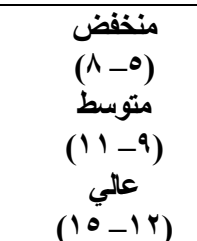 & $\begin{array}{l}\text { VY } \\
94 \\
\text { YY }\end{array}$ & $\begin{array}{l}r 4 \\
21 \\
17\end{array}$ \\
\hline 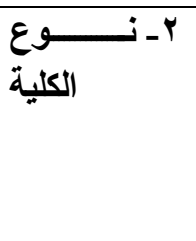 & نظرية & $\begin{array}{l}1 Y 4 \\
V \varepsilon\end{array}$ & $\begin{array}{l}4 T \\
T V\end{array}$ & 9- الجغافتي للوالـاح & 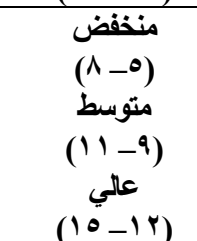 & $\begin{array}{l}09 \\
99 \\
\varepsilon 1\end{array}$ & $\begin{array}{l}r 1 \\
\leqslant 1 \\
r \leqslant\end{array}$ \\
\hline الَ- مهنة & 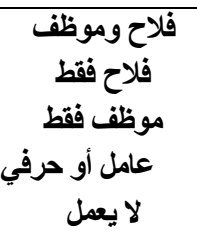 & $\begin{array}{l}94 \\
V Y \\
Y \varepsilon \\
4 \\
Y\end{array}$ & $\begin{array}{l}\varepsilon 1 \\
r 4 \\
i r \\
r \\
1\end{array}$ & الجغرافي اللوالدة الداح & 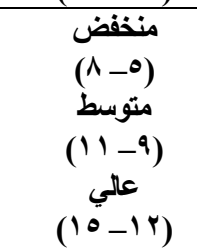 & $\begin{array}{c}171 \\
r \varepsilon \\
1\end{array}$ & $\begin{array}{l}\Lambda \varepsilon \\
i r \\
\varepsilon\end{array}$ \\
\hline ـــ مهن الو الدـــة & مورظة منزل & $\begin{array}{l}171 \\
r 4\end{array}$ & $\begin{array}{l}1 \varepsilon \\
19\end{array}$ & الثقافي اللمبحوثة & 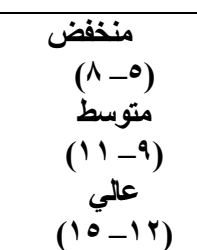 & $\begin{array}{l}r r \\
\varepsilon \Lambda \\
r .\end{array}$ & $\begin{array}{l}17 \\
r \leq \\
7 .\end{array}$ \\
\hline 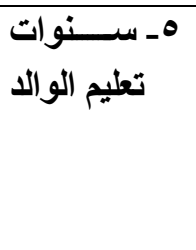 & 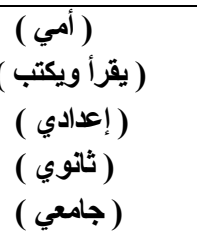 & $\begin{array}{l}7 \varepsilon \\
4 Y \\
17 \\
\vdots \\
\varepsilon 1\end{array}$ & $\begin{array}{l}r y \\
14 \\
\hat{r} \\
r . \\
r \varepsilon\end{array}$ & 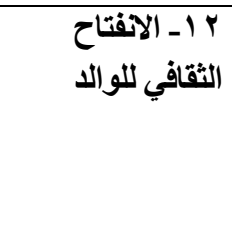 & 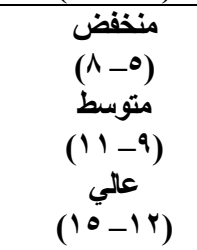 & $\begin{array}{l}\text { Tr } \\
\varepsilon . \\
r r\end{array}$ & $\begin{array}{l}75 \\
19 \\
17\end{array}$ \\
\hline 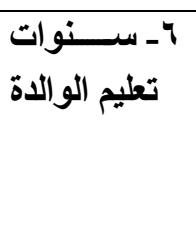 & 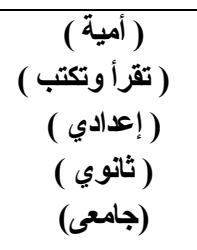 & $\begin{array}{l}9 \Lambda \\
r \Lambda \\
\Lambda \\
r \varepsilon \\
r r\end{array}$ & $\begin{array}{l}29 \\
19 \\
8 \\
15 \\
17\end{array}$ & الثقافي اللافوالدة & 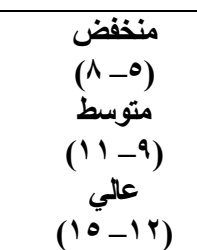 & $\begin{array}{l}1 \% 4 \\
\varepsilon \\
r \varepsilon\end{array}$ & $\begin{array}{l}i 1 \\
r . \\
i r\end{array}$ \\
\hline 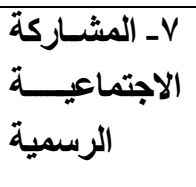 & عض عضو في في منظم أكثر & $\begin{array}{c}174 \\
r . \\
1\end{array}$ & $\begin{array}{l}A r \\
10 \\
r\end{array}$ & & & & \\
\hline
\end{tabular}

المصدر : جمعت البيانات وحسبت من استمارات الاستبيان 
جدول رقم (Y): توزيع المبحوثين مـن طلاب الجامعة الريفيين وفقا لمستوي

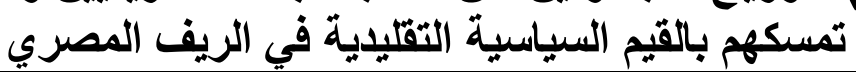

\begin{tabular}{|c|c|c|c|c|c|c|c|c|}
\hline \multirow{2}{*}{ القيم السياسية } & \multicolumn{2}{|c|}{ منخفضة } & \multicolumn{2}{|c|}{ متوسطة } & \multicolumn{2}{|c|}{ مرتفعة } & \multicolumn{2}{|c|}{ مجموع - مجوع } \\
\hline & عدد & $\%$ & عدد & $\%$ & عدد & $\%$ & عدد & $\%$ \\
\hline 1. التواكلية & 71 & $\Gamma \varepsilon$ & TrY & 7 & 1. & 0 & r... & $1 \ldots$ \\
\hline r. الاقتّار السياسي & 19 & $\wedge$ & 10r & vч & rr & 19 & r.. & $1 \ldots$ \\
\hline r. وضع النفس مكان الأخر & rr & 19 & $\Lambda \Lambda$ & \& & ^. & \&. & r... & $1 \ldots$ \\
\hline ؛. التوحد معه العائلة & & rr & $11 \%$ & 04 & $r \leq$ & ir & r.. & $1 \ldots$ \\
\hline 0. الخضوع السياسى & צ & rr & ד4 & ז & صفر & صفر & r.. & $1 \ldots$ \\
\hline ؟. الإيمان بالعدالة و المساواة & صفر & صفر & 01 & rq & $1 \leqslant r$ & $v_{1}$ & r.. & $1 \ldots$ \\
\hline v. الاتتماء & صفر & صفر & $r \varepsilon$ & ir & 189 & $\Lambda \Lambda$ & r.. & $1 \ldots$ \\
\hline
\end{tabular}

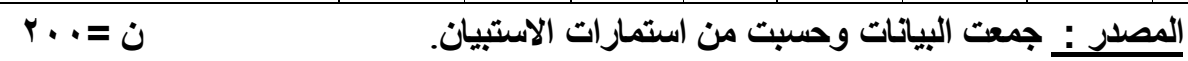

مستو اهم التعليمسي و انفتـاحهم الثقافي وارتفـاع مستوى تفكير هم و انتشــار أفكار العدالـة

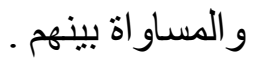

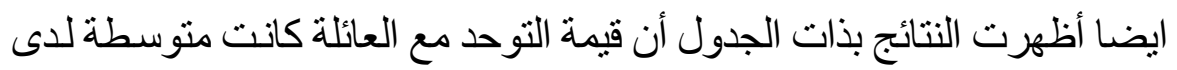

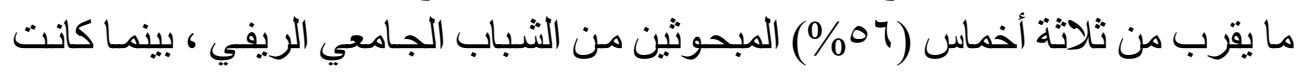

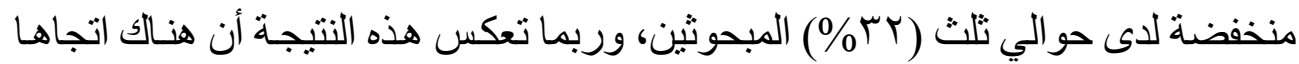

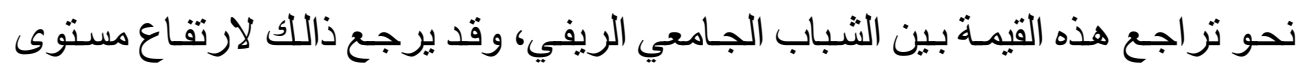

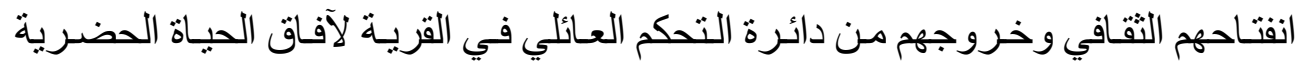

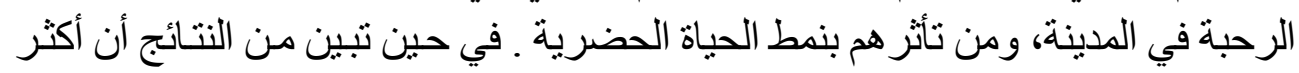

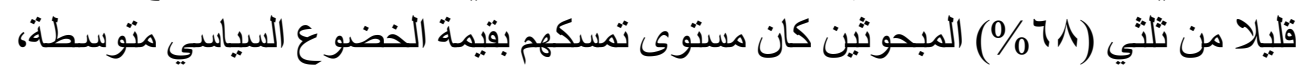

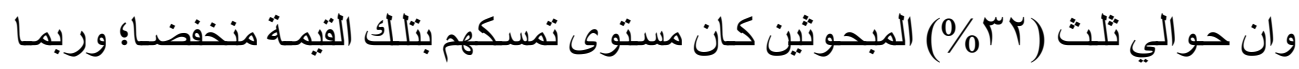

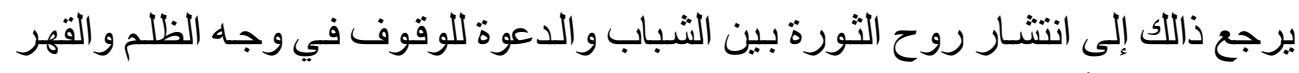

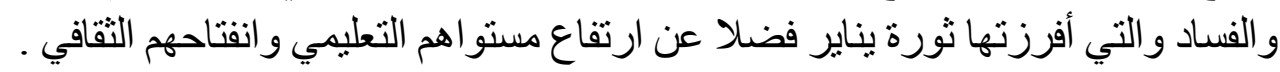

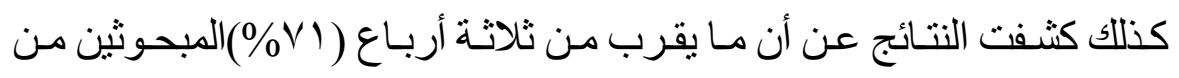

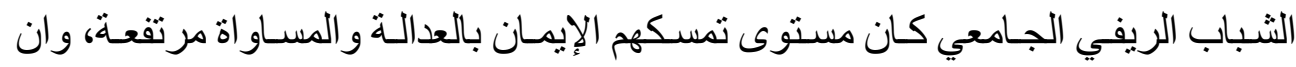

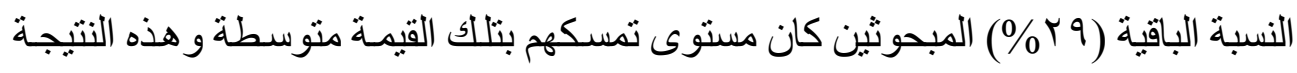
تثير إلي تعاظم تمسك الثباب الجامعي الريفي بقيمة العدالة والمساو اة، وربما يرجع ذالك 


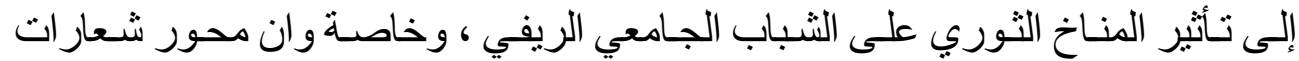

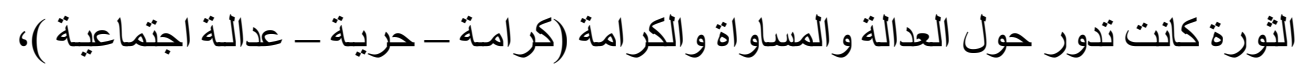

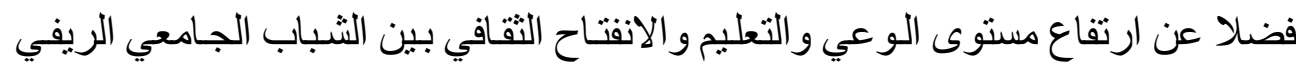

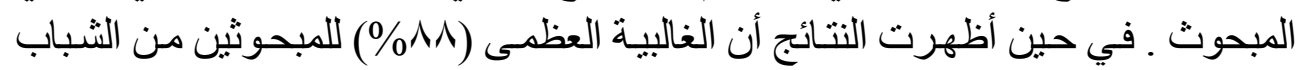

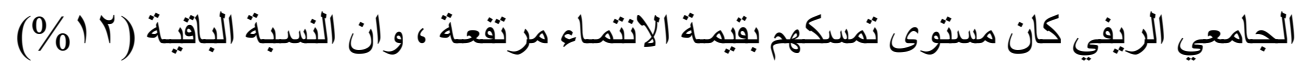

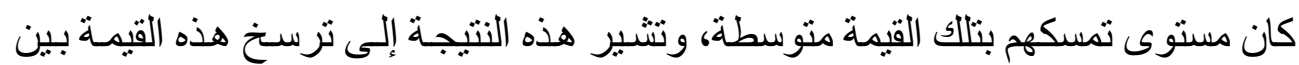

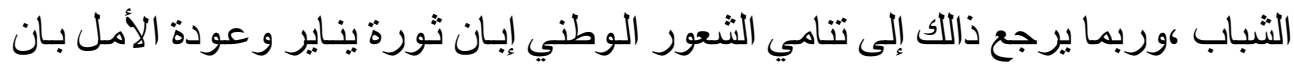

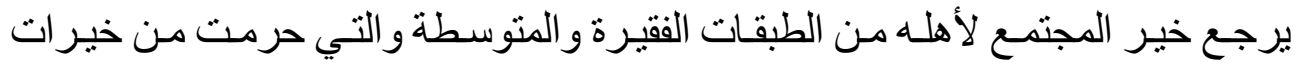

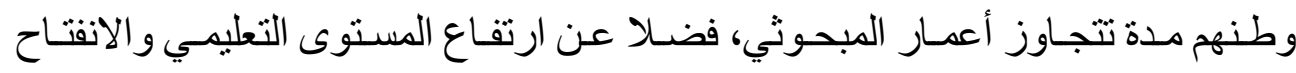

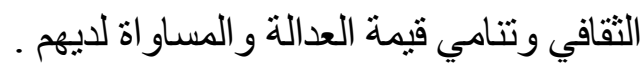

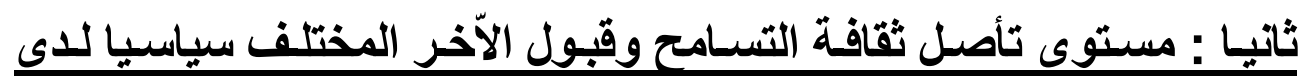

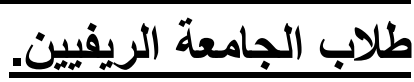

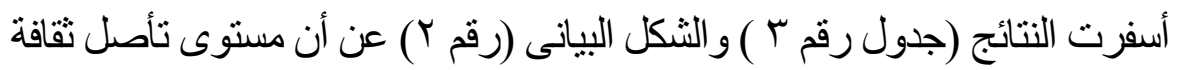

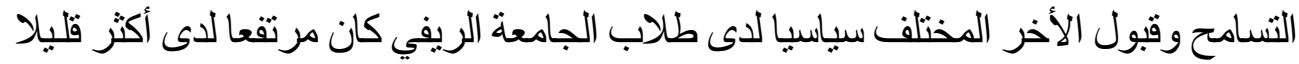

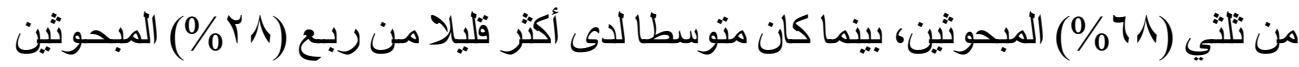

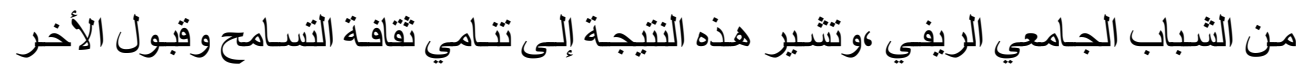

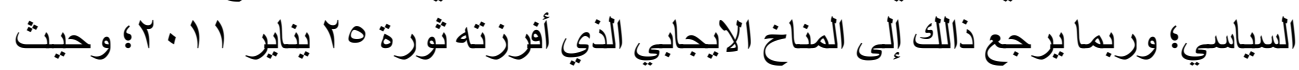

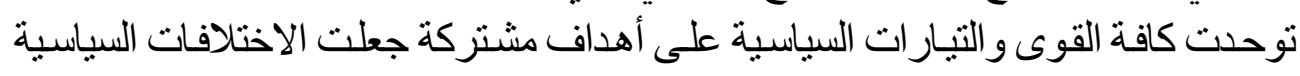

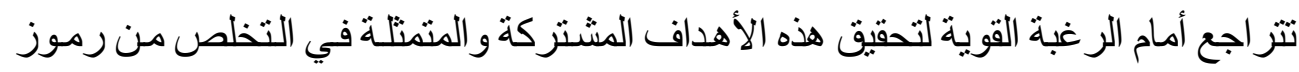

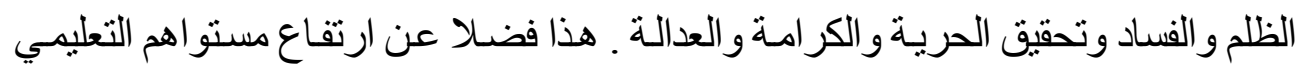

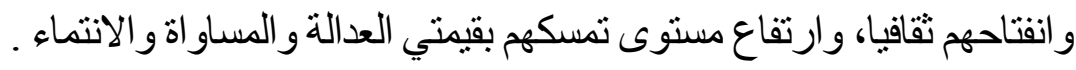

ثالثا : مستوى تأصل ثقافة التسامح وقبول الأخر المختلف دينيا لدى طلاب الجامعة الريفي : مينوي

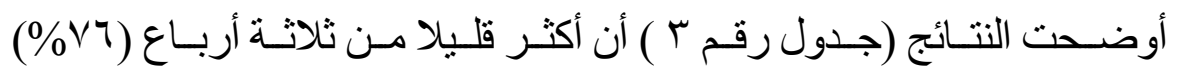

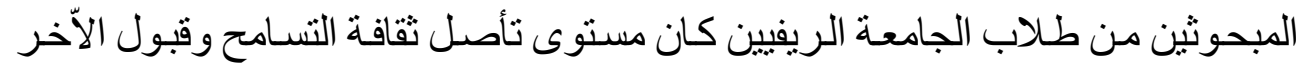

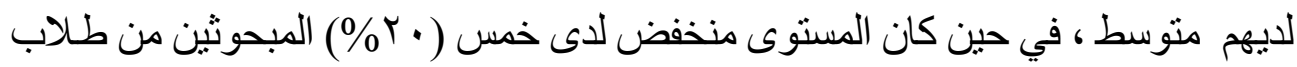

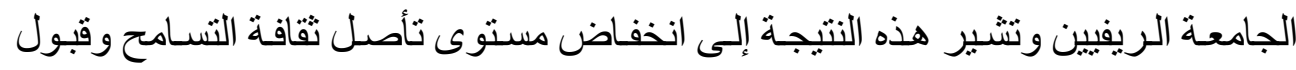
الآخر المختلف دينيا نسبيا بالمقارنة بالآخر المختلف سياسيا؛ وربما يرجع ذاللك إلى تلى 
جدول رقم (ץ): توزيع المبحوثين من طلاب الجامعة الريفيين وفقا لمستوي تأصل

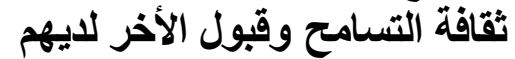

\begin{tabular}{|c|c|c|c|c|c|c|c|c|}
\hline \multirow{2}{*}{ تأصل ثقافة التسامح وقبول الأخر } & \multicolumn{2}{|c|}{ منخفض } & \multicolumn{2}{|c|}{ متوسط } & \multicolumn{2}{|c|}{ مرتفع } & \multicolumn{2}{|c|}{ 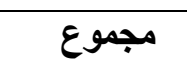 } \\
\hline & عدد & $\%$ & عدد & $\%$ & عدد & $\%$ & عدد & $\%$ \\
\hline 1. التسامح وتقبل الأخر السياسي & $\Lambda$ & $\varepsilon$ & 09 & YM & $1+4$ & 71 & r.. & $1 \ldots$ \\
\hline ז. التسامح وتقبل الأخر الديني & 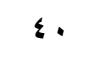 & r. & 10r & v4 & $\wedge$ & $\varepsilon$ & $r .$. & $1 \ldots$ \\
\hline rـ. التسامح وتقبل الأخر الحضاري & $1 . r$ & 01 & $9 \leqslant$ & $\leqslant \mathrm{v}$ & $\varepsilon$ & r & r... & $1 \ldots$ \\
\hline
\end{tabular}

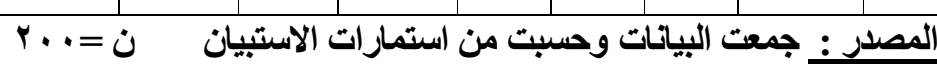

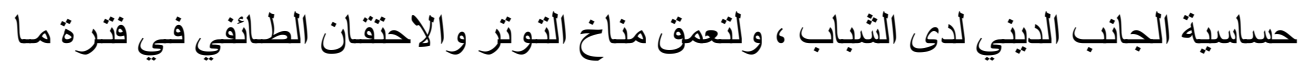

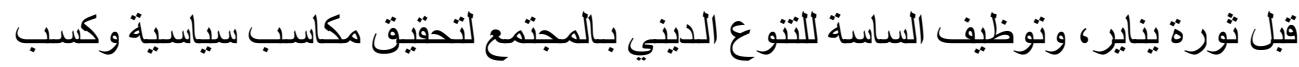

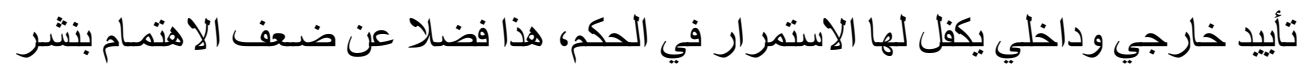

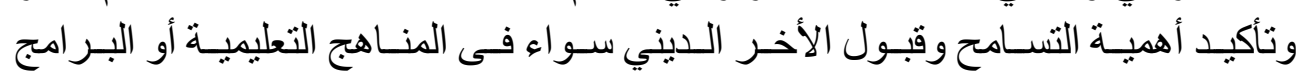

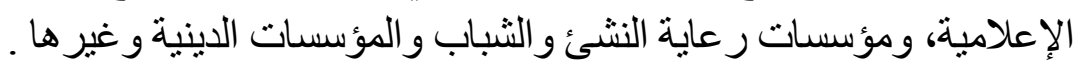

رابعا : مستوى تأصل ثقافة التسـامح وقبول الآخر المختلف حضـاريا للدي طلاب الجامعة الريفيني: مئوي تاهيل

كثفت النتائج (جدول رقم ؟) عن أن أكثر قلبلا من نصف (101\%) المبحوثين

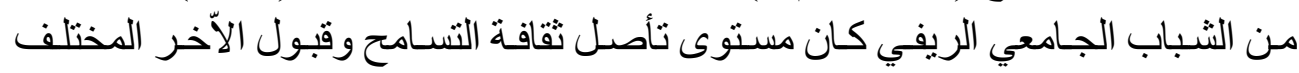

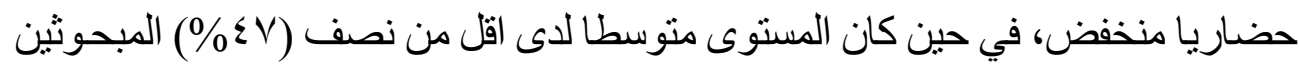

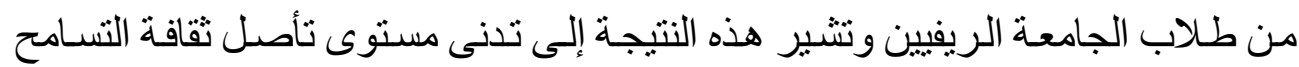

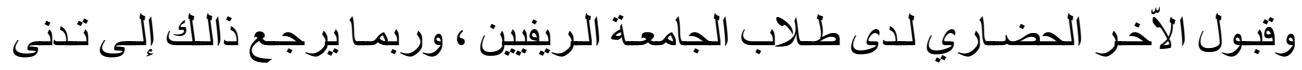

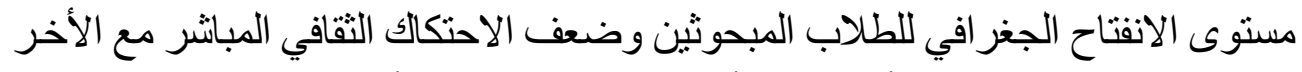

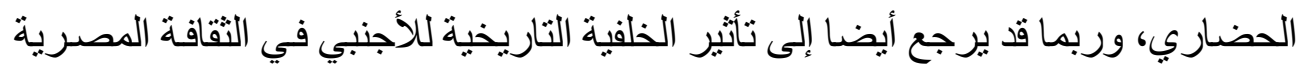

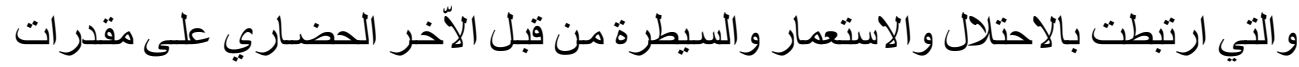

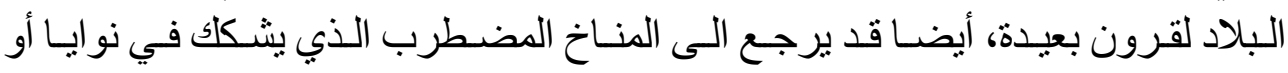

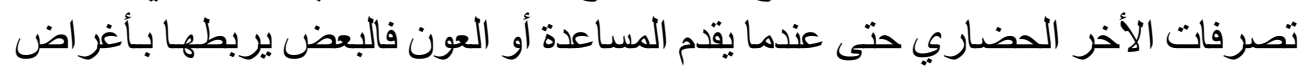

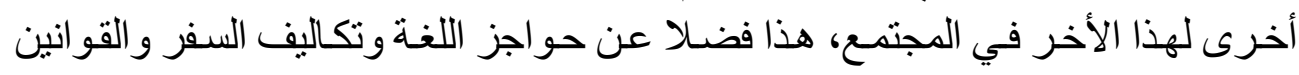

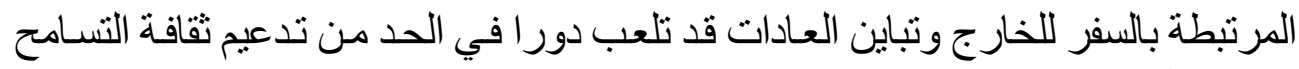

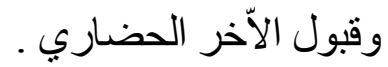


خامسا: العلاقة بين مستوى تأصل ثقافة التسـامح وقبول الآخر لدى طلاب

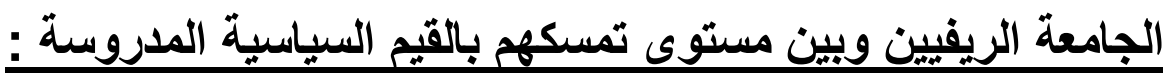

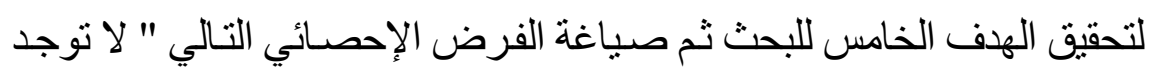

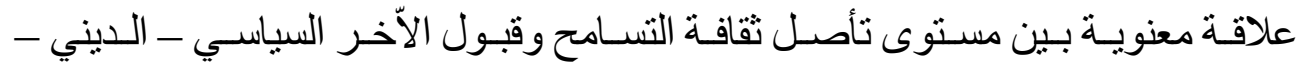

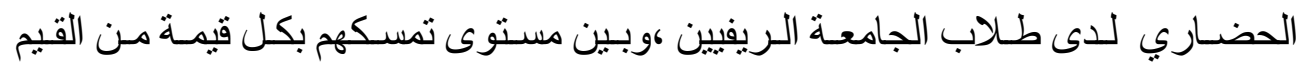

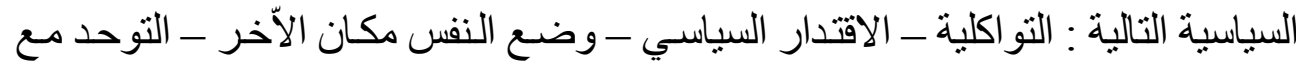

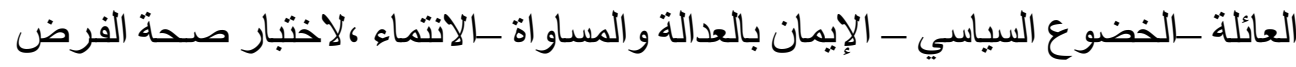
الإحصائي ثم استخدام معامل التطابق النسبي (كآ)

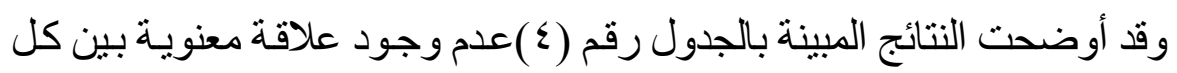

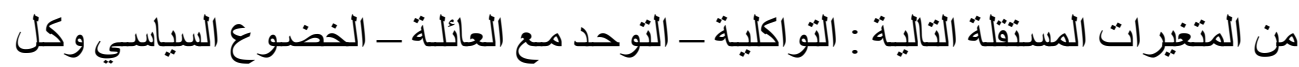

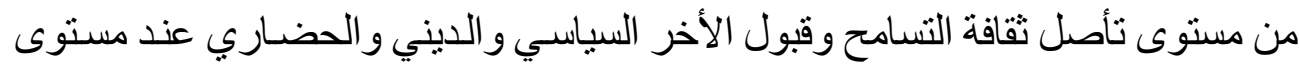

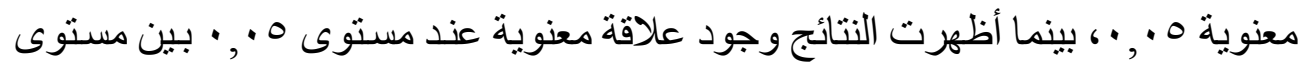

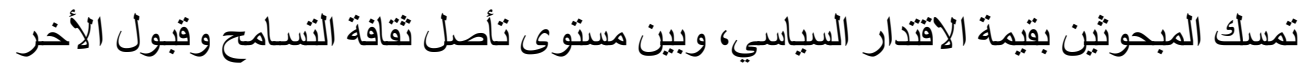

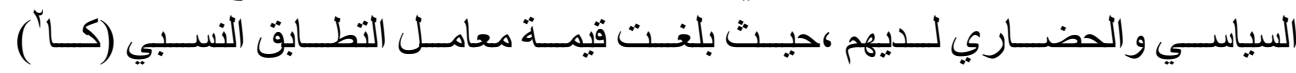

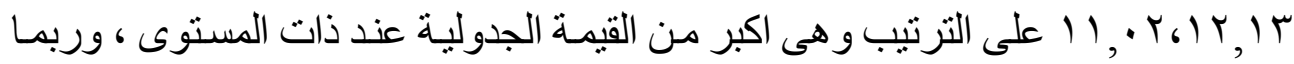

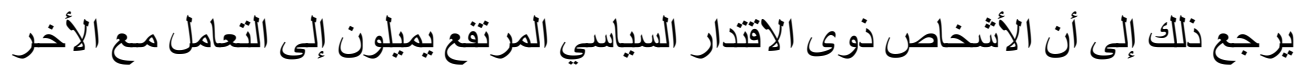

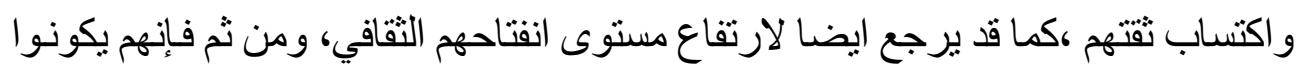

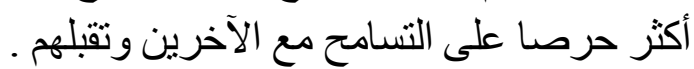

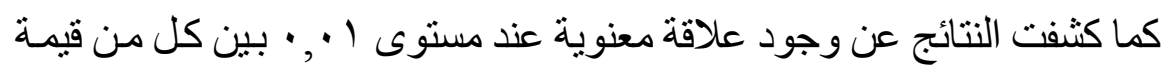

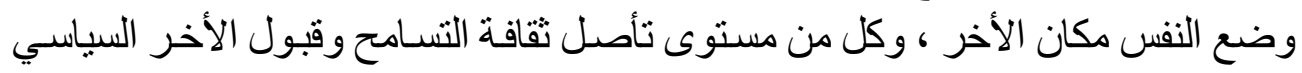

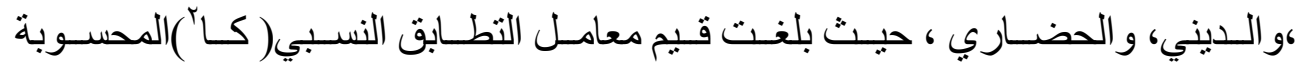

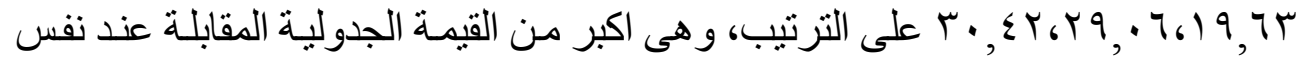

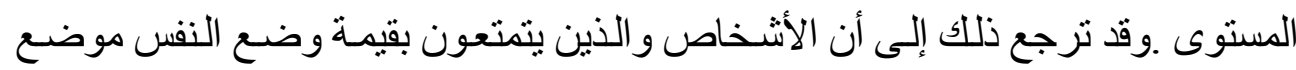

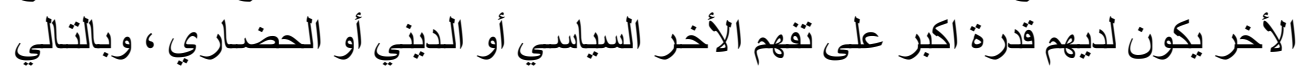

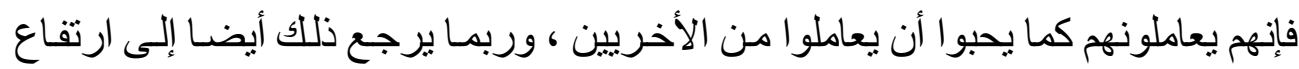

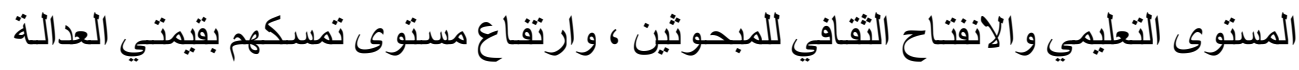

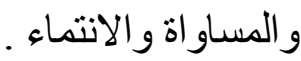


جدول رقم ( ) ): معاملات التطابق النسبي للعلاقة بين تقبل المبحوثين من طلاب الجامعة

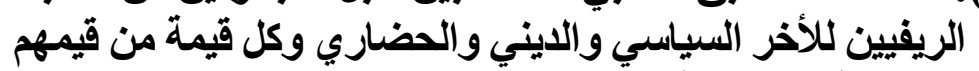

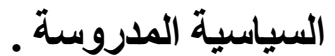

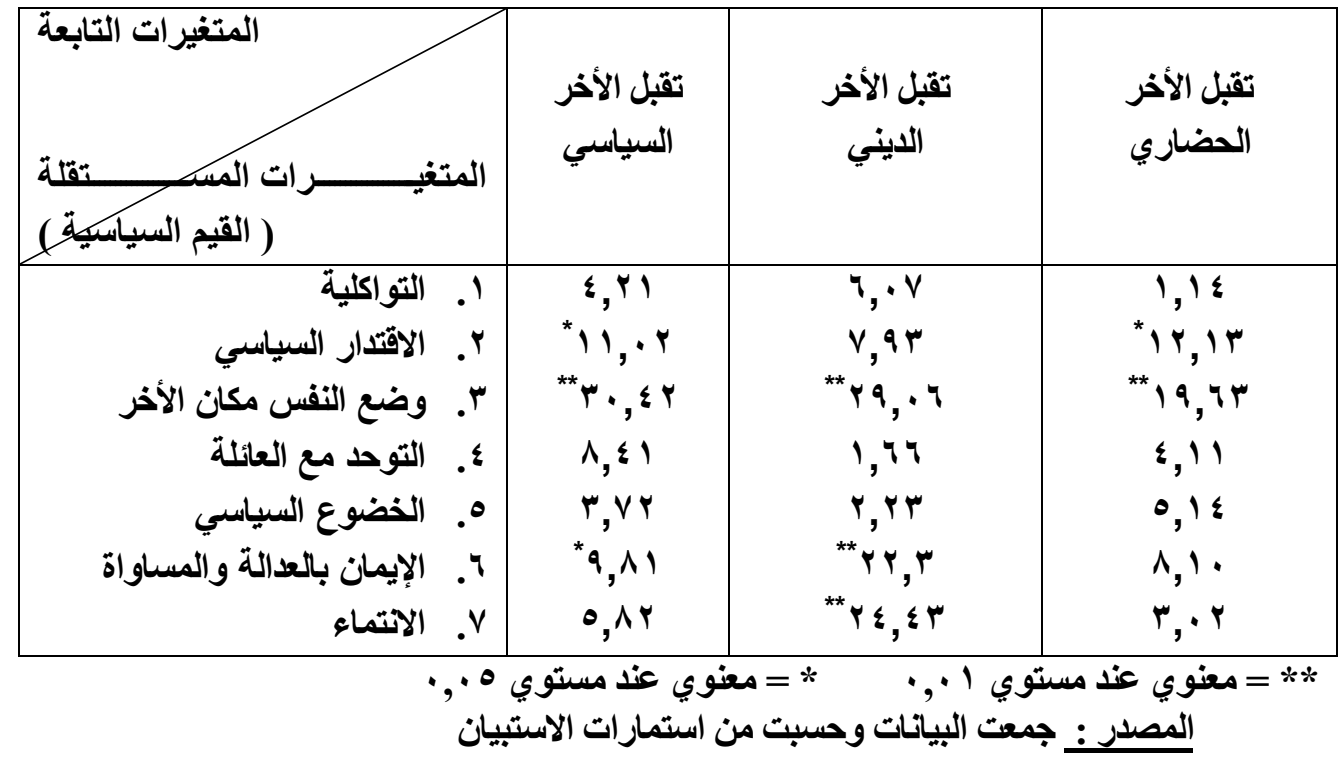

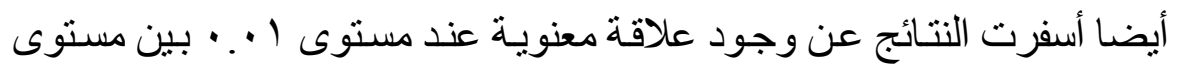

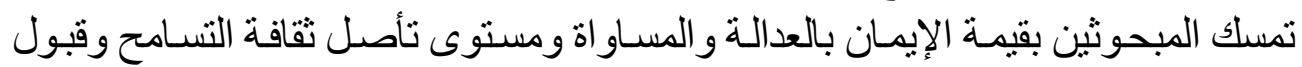

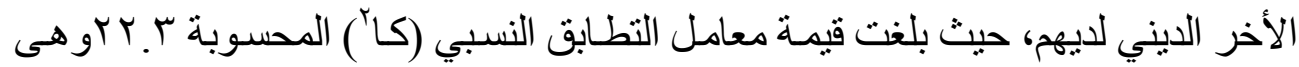

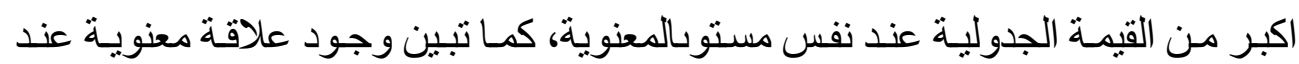

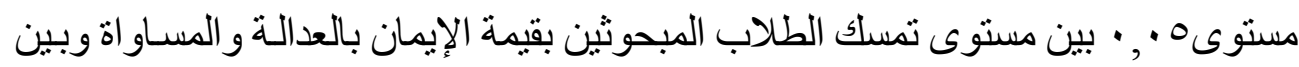

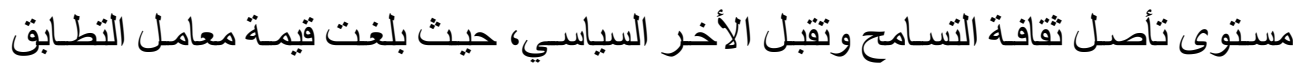

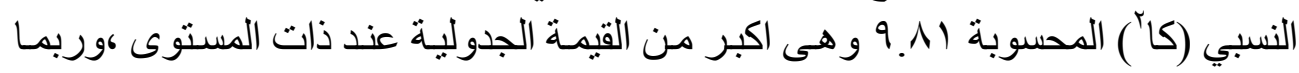

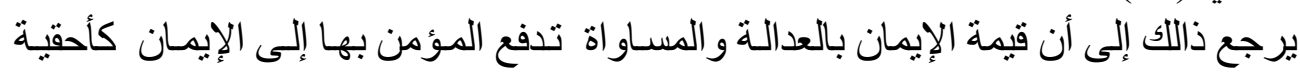

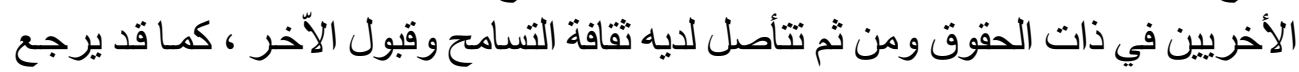

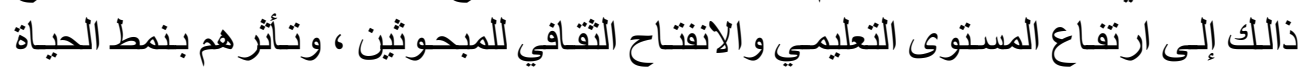

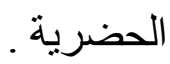

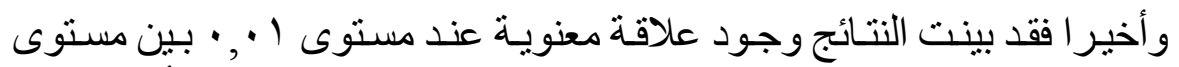

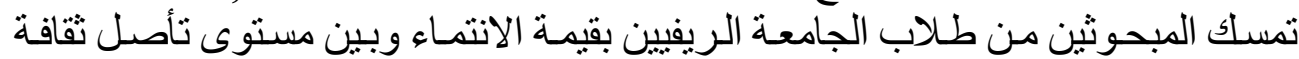

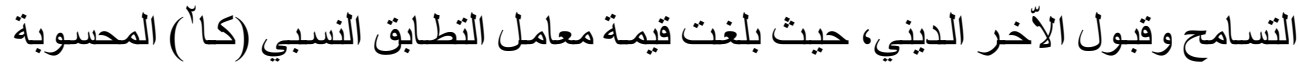


بـ ـ ؟ و هـى اكبر من القيمة الجدولية عند نفس المستوى؛ وربما يرجع ذلك إلى أن تأصل

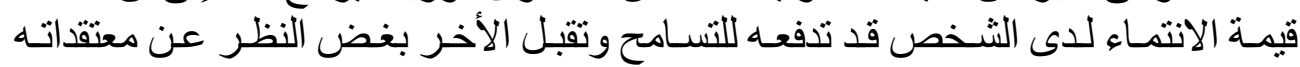
الدينية، وقد يرجع ذاللك إلى تأصل قيمة الإيمان بالعدالة و المسـاو اة لديهم وارتفاع الإع مستو اهم

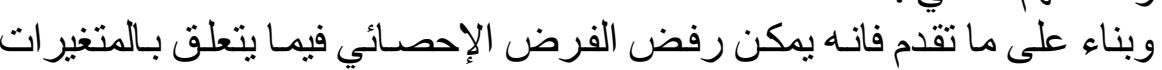

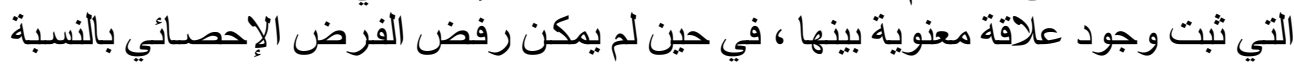

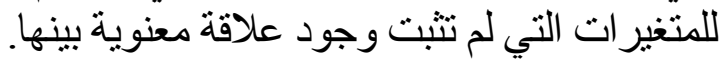

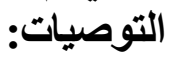

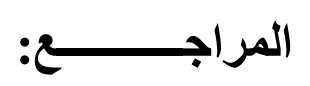

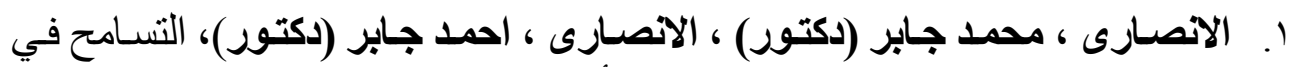

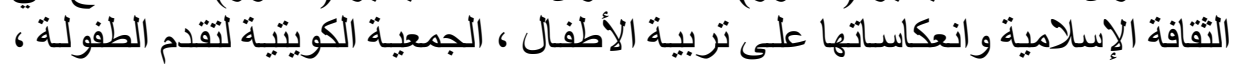

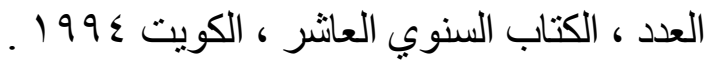

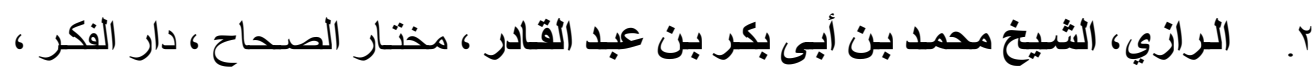

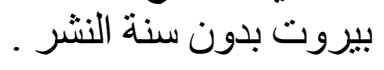

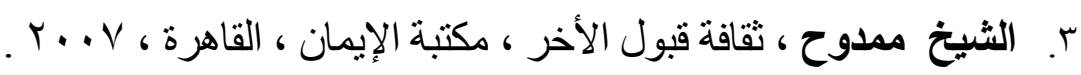

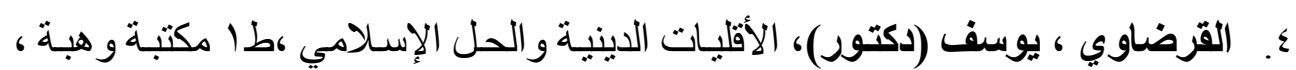

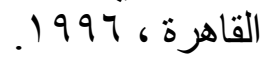
○. برستيد ، جيمس هترى ، فجـر الضـير ، ترجمـة د سـليم حسـن ، الهيئة المصـرية

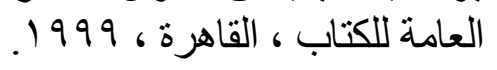

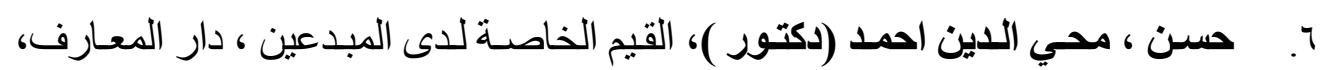

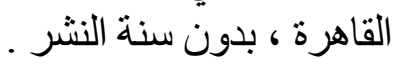

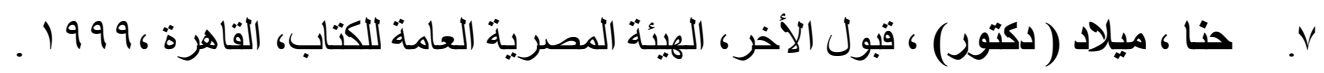

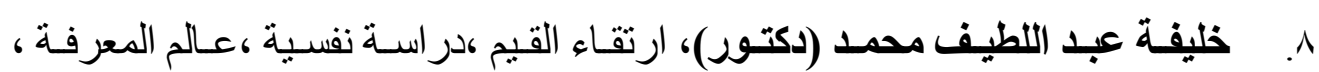

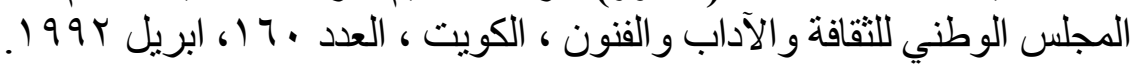




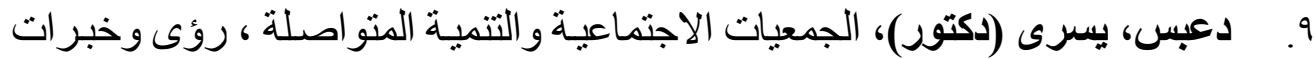

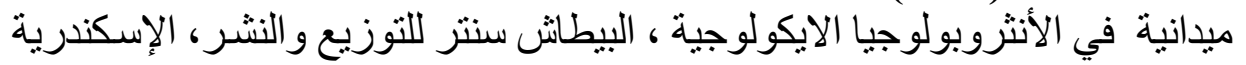
r... .

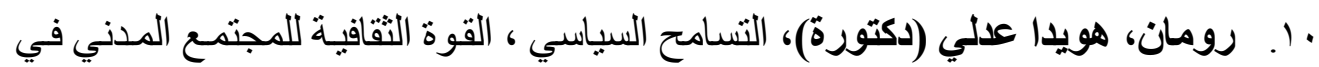

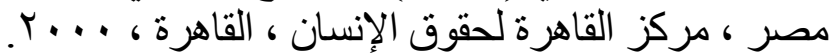

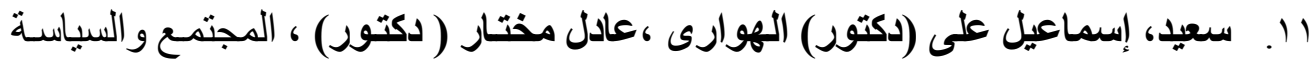

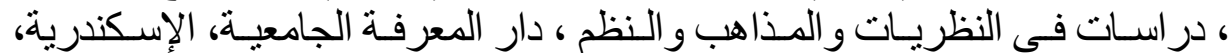
.

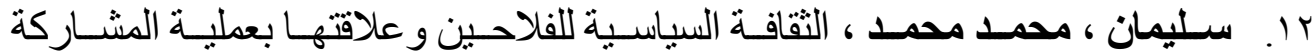

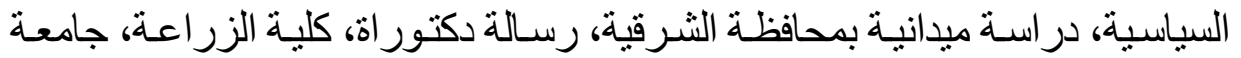

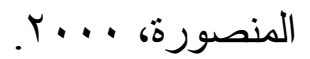

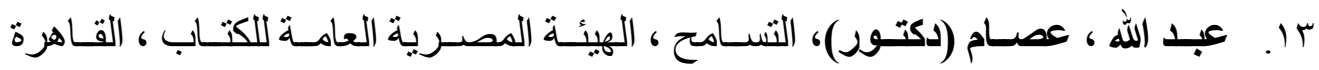
. r.. T،

ـ ا. . عبد الملكك ، كامل ،ثقافة التنمية ، " در اسة اثر الرواسب الثقافية على التتمية المستدامة

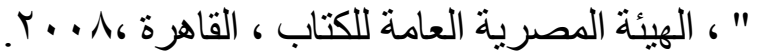

10. عبد الوهـاب ، اشـرف ، التسـامح الاجتمـاعي بين التراث و التغيير ، الهيئة المصرية

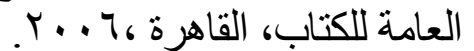
17 ا. غيـث محمـد عـاطف (دكتهور) ، قـاموس علم الاجتمــاع ، دار المعرفـة الجامعيـة،

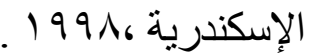

V Vاسـم ، خالد مصطقى (دكتور ) ، إدارة البيئة و التتميـة المستدامة ، الدار الجامعيـة ،

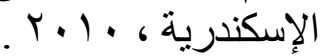
11. وكنـا كرى ، الأب باسيليوس ، الكتاب المقدس للمدر اسـة والعائلة في العهدين القديم

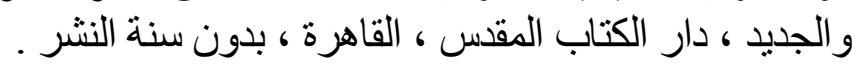

9 1. مـدكور، إبـراهيم بيـومي ،وآخـرون (دكــاترة)، معجم العــوم الاجتماعيـة ، الهيئة

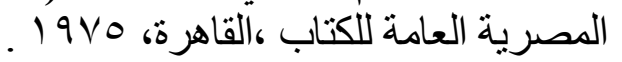

· r. . وهبة ، مراد (دكتور)، التسامح الاجتماعي، مكتبة الأنجلو المصرية ، القاهرة ، 9NV.

21. http://.www maaber,50 mgs.com 18-6-2011.

22. Rokcach,M., the Nature of Human valus ,the free press,N.Y .1973 P.56.

23. Tinder,G., Tolerance Toward a New civility, Amherst,univ. of massochetts, press, U.S.A, 1976, p.30. 


\title{
SOME POLITICAL VALUES OF RURAL UNDERGRADUATE STUDENTS AND ITS RELATIONSHIP WITH ROOTING TOLERANCE CULTURE AND ACCEPTANCE OF THE OTHER AFIELD STUDY IN SHARKIA AND ASSUIT GOVERNORATES
}

\author{
Ibrahim A. A. Khalifa
}

Rural Sociology Depart.,Faculty of Agric.,Azhar Univer., Branch Assuit, Egypt

\section{ABSTRACT}

The study aimed at identifying the rural undergraduate students' holding level of some traditional political values in rural community, identifying the rooting level of tolerance culture and acceptance of the other and finally determining the relationship between the students holding level of studied values and level of tolerance culture and acceptance of the other.

The study was conducted on a random sample of rural undergraduate students in both Sharkia and Assuit governorates with a total sample size of 200 respondents ( 100 from each ), and data were collected by using personal interview questionnaire during March and April, 2011. The following statistical methods were used: frequencies, percentages and relative contingency coefficient (Chi-square test).

The following represent the most important results of the study: _ The most practical value that were held by the respondents were: belonging value, followed by the value of faith in justice and equality, then the value of sensing others, representing about $88 \%, 71 \%$ and $40 \%$ respectively.

_ The heighest degree of accepting the other was the acceptance of political point of view representing about $68 \%$.

_ A relative relationship was revealed the value of sensing others and respondents' acceptance of others political, religious and civilization point of view.

Conclusively,

Keywords: Political values, rural undergraduate students, rooting tolerance culture, Sharkia \& Assuit Governorates 